\title{
An Investigation of Taiwanese Nursing Students' English Learning Behaviors and Environmental Factors Related to English Learning before and after Their Internship Experiences-A Case Study
}

\author{
Yi-An Hou \\ St. Mary's Junior College of Medicine, Nursing and Management, Taiwan \\ Email: hyn@smc.edu.tw
}

How to cite this paper: Hou, Y.-A. (2017) An Investigation of Taiwanese Nursing Students' English Learning Behaviors and Environmental Factors Related to English Learning before and after Their Internship Experiences-A Case Study. Open Journal of Nursing, 7, 1439-1473.

https://doi.org/10.4236/ojn.2017.712102

Received: November 2, 2017

Accepted: December 23, 2017

Published: December 26, 2017

Copyright $\odot 2017$ by author and Scientific Research Publishing Inc. This work is licensed under the Creative Commons Attribution International License (CC BY 4.0).

http://creativecommons.org/licenses/by/4.0/

c) (i) Open Access

\begin{abstract}
The study aimed to investigate Taiwanese nursing students' English learning behaviors and environmental factors relevant to English learning before and after their internships. More than five hundred nursing students from five junior colleges in southern Taiwan served as subjects of the study. The research instrument included a 134-item questionnaire dealing with students' personal demographic information and English learning behaviors of motivation, strategy, and anxiety. In addition, environmental factors relevant to English learning of English as the Medium of Instruction (EMI) and Internationalization at Home (IaH), as well as nursing English for practicum use were discussed. Findings revealed that some correlations among students' English learning behaviors, environmental factors, and English levels did exist before and after their internships. Moreover, students' internship experiences of English use also brought about some changes in their learning behaviors led to English levels. Some implications and suggestions were provided for schools and students hoping to equip students with good English skills before getting into the job market.
\end{abstract}

\section{Keywords}

English Learning Behaviors, Environmental Factors, Nursing Internships

\section{Introduction and Purpose of the Study}

\subsection{Introduction}

As globalization has brought about a new society, English has become the lingua 
franca, the principal language for communication in many fields. In Taiwan, there are about six hundred and forty thousand foreign residents from more than 167 countries (Taiwan National Immigration Agency,

http://www.immigration.gov.tw//, 2016), that is to say that more than $2.7 \%$ of the whole Taiwanese population are foreigners. In such circumstances of having more and more foreign residents, and with the increasing number of aging and diverse foreign patient population in the society, access to health care will expand and the need will increase for more competent and diverse nursing graduates, particularly with adequate English proficiency and cultural knowledge and sensitivity to care effectively for the increasing diverse foreign patient population. However, are the nursing graduates who will be standing in the front line of health care in Taiwan ready for the opportunities and challenges? Are they highly motivated to learn English and equipped themselves with good English ability before getting into the job market?

\subsection{Purpose of the Study}

The study intended to investigate how nursing students learn English during their pursuing associate degree period, including school's environmental factors, students' English learning behaviors and their English levels. In particular, the study intended to find out if students' medical internships brought about any impacts on their English learning behaviors and performance.

\section{Literature Review}

Related studies about: 1) English learning motivation and attitude, 2) language learning strategy use, 3) anxiety about foreign language learning, 4) environmental factors related to English learning (EMI, IaH), and 5) nursing students' internship experiences of English language use were reviewed as follows:

\subsection{Foreign Language Learning Motivation and Attitude}

Gardner and Lambert (1959) [1] were the first to publish the investigation of the relationship of attitudes and motivation to second language achievement. For motivation, Gardner \& Lambert (1959) [1] began to define it as Integrative Orientation and Instrumental Orientation. The former is "based on a desire to become more like valued members of the target language community," (Gardner \& Lambert, 1959: p. 267) [1] and the latter is that "which reflects a determination to acquire another language to achieve such goals as a good job or social recognition" [2]. In Gardner's (1985) [3] Socio-educational Model of second language acquisition, learners with an integrative orientation are more interested in learning the language, have favorable attitudes about the language community and a general openness toward the other groups of people. In addition, integratively motivated learners tend to determine long-term success in foreign language learning. Hence, it's believed that integrative orientation plays a more important role in English as Second Language (ESL) settings than English as 
Foreign Language (EFL) ones, where learners have limited contact with the foreign language's people and culture, in such circumstances as some Asian countries, instrumental orientation used to be proved to be more helpful in successful foreign language learning achievement. However, due to the recent trend toward globalization and internationalization, English has become the Lingua Franca-a tool of communication and interaction with people from different countries of the world, hence, integrative orientation has been regarded as important as instrumental orientation in influencing learners' foreign language success both in ESL and EFL settings.

As for attitude, Titone (1990) [4] focused on the role of attitude in second language learning. He indicated that attitudes strictly tied up with motivational dynamics work most powerfully, especially in acquiring mastery in a second language. However, the causal relationship between attitude and achievement is contradictory. Positive attitude may cause satisfactory achievement. On the other hand, successful achievement may breed positive attitudes. Unlike aptitude, attitudes are not inborn and can be developed and cultivated. In any event, it was suggested that "Developing sound attitudes is the first step toward the achievement of bilingualism" [4]. Since then, attention was shifted from the study of learner's behavior to the learning process of language learners. It was this shift that gave definition to the field of second/foreign language learning. In Taiwan, after the implementation of English Education in elementary schools, many studies found that motivation is the most important factor in English learning and proved to be related to attitude and motivational intensity [5], though some findings failed to find out such relationship between motivation and English achievement [6]. In spite of that, motivation has been found to be related to other factors predictive to students' English scores, including strategy use [7], indicating that better language learners tend to have stronger motivation and use more strategies; anxiety [8], showing that anxiety is negatively related to motivation and predictive to English scores; and even genders [9], indicating that gender differences not only exist in multiple intelligences but also in English learning behaviors.

\subsection{Language Learning Strategy Use}

Learning strategies are "specific actions taken by the learner to make learning easier, faster, more enjoyable, more self-directed, more effective, and more transferable to new situations" (Oxford, 1990: p. 8) [10]. Learning strategies are variously defined as approaches to increase learners' desire to solve the problems, to accomplish the task, to meet the objectives, and to attain the goals [10]; keys to greater autonomy and more meaningful and practical effects in language learning; and procedures and techniques applied by learners to facilitate their acquisition, storage, retrieval, and use of information [11]. Numerous research findings showed that language learning strategies significantly influenced students' language learning [10] [12]. 
Several language learning strategy theories have been discussed in the past several decades [10] [13]. Among them, one theory that has frequently been employed around the world is Oxford's (1990) [10] language learning theory. Oxford's theory was developed based on a synthesis of previous research, factor-analytic, questionnaire-based studies of language learning strategy among adult learners, and research from the field of cognitive and educational psychology. Accordingly, her theory has not only been widely used to investigate ESL/EFL students' learning strategies based on their cultural backgrounds but also has been extensively measured for reliability and validity. Oxford (1990) [10] divided strategies into six subcategories, including memory strategies, cognitive strategies, compensation strategies, metacognitive strategies, affective strategies, and social strategies. The first three strategies were defined as direct strategies, while the rest three were indirect ones.

To begin with direct strategies, memory strategies are ones applied to help the learner remember and retrieve new information. Cognitive strategies are used to understand and produce the new language and involve active practicing, receiving and sending messages, analyzing and reasoning, and creating structure for input and output. Compensation strategies are selected to make up for gaps in knowledge, usually by guessing, and are used to overcome limitations in speaking and writing. In contrast to direct strategies, indirect strategies like metacognitive ones are chosen by learners to coordinate and regulate their cognitive process in creating, arranging, planning, and evaluating learning. Affective strategies help learners regulate and manage their emotions in language learning while social strategies are applied to improve understanding of the target language through communication with others. To sum up, the Strategy Inventory for Language Learning (SILL) based on Oxford's theory has been frequently used to discover students' learning strategies while studying English [14] [15] [16] [17]. This instrument helps language teachers recognize students' learning strategies and then provide multiple teaching approaches to match students' diverse needs depending on their individual learning strategies.

\subsection{Anxiety about Foreign Language Learning}

Learning is "the process of acquiring relative permanent change in understanding, attitude, knowledge, information, ability and skill through experience" (Wittrock, 1977: p. ix) [18]. According to Information-Processing theorists, learning can be divided into three stages: sensory register, short-term memory, and long-term memory. During the three learning stages, anxiety may occur anytime, and affect learning performance. Not until 1978, when Scovel (1978) [19] reviewed the sparse literature concerning anxiety's role in language learning, did researchers become interested in investigating the role of anxiety about foreign/second language learning. Nevertheless, many findings are inconsistent and unable to establish a clearcut relationship between anxiety and overall foreign language achievement [19] [20], nor establish a clear picture of how anxiety affects language learning and performance. It is obvious that many learners regard 
foreign language learning as an anxiety-provoking experience which affects their language performance in one way or another. Hence, the influence of anxiety in foreign language learning cannot be ignored.

Learning anxiety is "a distinct complex of self-perceptions, beliefs, feelings, and behaviors related to classroom language learning" (Horwitz, Horwitz, \& Cope, 1986: p. 128) [20], which is likely to arouse in language learning stages: input, processing, and output [22] and affect language learners' performance. MacIntyre (1995) claimed that "Language learning is a cognitive activity that relies on encoding, storage, and retrieval processes, and anxiety can interfere with each of these...” (p. 96) [23].

Language anxiety's effect on language learning is two folds: positive and negative. On one hand, appropriate tension is normal and necessary. It is suggested that some anxiety can improve performance [19] [24], positively relate to motivation, and influence both the quality of performance and the amount of effort invested in it. For students with higher self-esteem and strong motivation, anxiety may force them to study harder, arouse their potential and bring about unanticipated better outcome. On the other hand, anxiety's another affect lies in its negative influences on other variables, such as motivation, attitude, and strategy use, as well as in its interfering with language learning process and performance. Gardner and MacIntyre (1992) [25] pointed out that "Anxiety may lead to a reduction in motivation" (p. 212). Such negative relation was also found between anxiety and attitude. Trylong (1987) [26] found that students who were very anxious tended to have lower scores on the attitude measure. Anxiety is was found to be negatively related to attitude and motivational intensity and influenced students' strategy use to compensate their weakness [12]. It seems that students with higher language anxiety tend to be less motivated and hold less positive attitudes toward foreign language learning, and use less learning strategies as well.

Additionally, anxiety's negative effect in interfering with language learning has had lots of evidence. Findings show that anxiety is negatively correlated with the following consequences: Field Independence, which is strongly associated with the time spent and attitude [27]; participation of classroom activities, short-term and long-term memory, numbers of words being learned, the rate of vocabulary learning [23]; TOEFL scores [27]; course grades [23]; and language achievement [8] [12] [20] [21]. All may cause learning difficulties and influence students' efficiency in language activities; self-confidence; and even students' represented ability [23]. Consequently, language anxiety may bring about unsatisfactory language outcome.

According to Horwitz, Horwitz, and Cope (1986) [20], learning anxiety is "a distinct complex of self-perceptions, beliefs, feelings, and behaviors related to classroom language learning" (p. 128), and may occur any time during the learning process. Horwitz, et al. (1986) [20] divided the 33 items of the Foreign Language Classroom Anxiety Scale (FLCAS) into three categories relating to general sources of anxiety, including communication apprehension, test anxiety, 
and fear of negative evaluation.

Particularly, an interesting finding was found in Hou, et al.'s research (2012) [8] that 'Teachers' beliefs have impacts on their students' anxiety about foreign language learning" (p. 250). For example, comparing with American teachers, many Chinese teachers tend to emphasize more on the importance of grammar, excellent pronunciation, and immediate error correction. Consequently, Chinese students are more anxious than American students about feeling overwhelmed by the number of rules, being laughed at by other students, and being corrected by teachers whenever they make a mistake. Hence, it is suggested that teachers be aware of the cultural differences of anxiety when teaching Asian students.

\subsection{Environmental Factors Related to English Learning (EMI, IaH, ICICE)}

Research studies have indicated that language learning is influenced by various factors, including cognitive factors (learning styles, learning strategies $\cdots$ ), affective factors (motivation, attitude, anxiety...), and personal factors (age, gender, environment, culture $\cdots$ ) [28]. To promote internationalization in Taiwan's higher education system, one of the initiatives is to encourage colleges and universities to teach by using English as the medium of instruction (EMI) to provide students with more internationalized perspectives, and to create international programs, such as Internationalization at Home $(\mathrm{IaH})$ to accommodate international and domestic students to learn and interact with one another by using English.

On the other hand, due to the fact that vocational/technical education in Taiwan used to emphasize more on "career preparation education" and prepare to engage in more practical skills, some courses in vocational/technical curriculum were not regarded as core courses with more credit hours as that of other general schools in the past years, and English was one of them. As a result, without being placed great emphasis on foreign language study, many vocational/technical school students' English proficiency was normally worse than that of general schools. However, after the access to the World Trade Organization (WTO) in January, 2002, the impact of industrialization, and to face the challenge of the knowledge economy, vocational/technical school students' unsatisfactory English proficiency began to attract much more attention than ever before. Hence, Department of Technical and Vocational Education in Taiwan Ministry of Education, in addition to providing some grants for improving students' English proficiency, began to set up Information Center for International Cooperation and Exchange (ICICE) to promote students' foreign language ability from 2008, and then changed to be the Department of International and Cross-strait Education (DICE) (http://english.moe.gov.tw/) in 2013. Since then, technical/vocational schools have been applying for some grants to hold activities related to foreign language learning, and sending students abroad for the purposes of studying, internships, and service learning.

No matter what strategies the schools adopt, when students have chances to 
experience the whole English-Medium Instruction (EMI) or participate in the cross-cultural activities, held domestically ( $\mathrm{IaH}$ ) or abroad, they will develop cross-cultural awareness and represent their most immediate meaningful contact with the target language itself, which is believed to be able to bring about some changes toward English learning for the participating students. Findings have pointed out that in EMI programs, where English is the only language for communication, having more exposure and opportunities to use it, students generally show a higher level of motivation [29], more positive attitude toward the program and lead to an improved perception of English proficiency [30]. In addition, Chen \& Kraklow (2015) [31] even found that there were significant differences in both intrinsic motivation and English learning engagement between students in EMI and Non-EMI programs. Nevertheless, in spite of the advantages mentioned above, the EMI and IaH programs cannot work out if students' English proficiency is not high enough, teacher's preparation is not adequate, administrative support is not sufficient, and curriculum integration is not effective [32].

As for other advantages of the cross-cultural exchange dealing with students' language learning environment, in Tsai's study (2012) [33], 150 EFL Asian students studying abroad in a university of the United States were found to be motivated both instrumentally and integratively. In that cross-intercultural contact, English has already become very much a part of their lives of the students. Hence, the students are expected to be motivated to learn English with more integrative orientation. More importantly, it is known that language and culture are inseparable. In the field of L2 motivation, contact was regarded as a key factor and inter-cultural contact was believed to be a means and an end in L2 studies, which can bring about linguistic consequences, self-perceptions of identity [34], positive attitudes [35] [36], lower anxiety, and strong motivation [37] [38], because in inter-cultural contact students have to be able to use the language less, as an object of study in school, and more as an additional language of their own to do the cross-intercultural communication. Especially in many ESL settings like Asian countries, where learners have limited contact with L2 speakers or their culture, where an instrumental orientation may be more important in promoting successful learning, inter-cultural contacts tend to play a more helpful role either by direct contact or indirect contact, such as music, movies, programs. It can be expected that being provided by appropriate English learning environment, students will be able to use the language more as an additional language for inter-cultural communication than as an object of study in school, and become truly-motivated to make efforts on learning, enjoy the learning tasks, and lead to better achievement by having more positive attitude, more strategies, lower anxiety and higher self-confidence.

Nevertheless, as mentioned by Robert, Chou, \& Ching (2010) [39], when increasing numbers of schools commit to internationalization mostly sponsored by Taiwan government scholarships, it should not be ignored how to attract more international students to contribute to the host schools' campus life for 
domestic students. On the other hand, it should be paid more attention about those exchange study-abroad returnees' learning attitude and behavior in the classroom, as well as the domestic teachers' belief toward those returnees with better English communication fluency and cultural understanding who might have self-superiority and race-based prejudice of being taught for a period of time by native speakers of English in an English speaking country [40]. Consequently, all the attitude and behavior of those exchange study-abroad returnees might cause teachers or even classmates to feel uncomfortable in the classroom, which might have some negative effects on the exchange study-abroad returnee students on campus.

\subsection{Nursing Students' Internship Experiences of English Language Use}

What with the increasing international population in Taiwan, and what with the fact that English has become the lingua franca, though English is widely used in medical practice in Taiwan, nurses still bear a lot of institutional pressure from medical practice to use English in interaction with physicians, other health professionals, and even international patients. Under such circumstances, student nurses can't avoid having more chances to use English in their medical practice.

However, Su \& Kuo (1993) [41] indicated that in the relationship between nursing students' practice anxiety and stress, the top source was "insufficient personal ability" stress (p. 175). Sheu \& Huang (2001) [42] also pointed out that "unfamiliar with medical records and terminology" was the second stressor, just next to "lack of experience and ability in providing nursing care and in making judgements" (p. 238). In addition, Yang (2011) [43] claimed that many clinical nurses in Taiwan were not adequately prepared to communicate with foreign clients or to use English when delivering nursing care services, hence, it might happen that "medical staff sometimes back away when they meet foreigners" (Lee, 2016: p. 94) [44].

Lee (2016) [44] conducted an important study about "Need analysis on English language use in nursing: A comparison between certified nurses and student nurses", in which subjects were 157 student nurses and 60 certified nurses. The participating 157 student nurses, who had completed their medical-surgical nursing practice, were from 5 five-year junior colleges and 2 universities offering junior college's nursing programs in Northern Taiwan. As for the 60 certified nurses, they were working in hospitals or healthcare institutions for a minimum of one year. Lee (2016) [44] found that not only student nurses but also certified nurses were weaker in productive English skills (speaking and writing) than receptive skills (listening and reading), especially, student nurses regarded English listening as the most important ability in the nursing workplace, followed by speaking, reading, and writing. As for certified nurses, English reading ability is the most important for them, followed by listening, speaking, and writing. Nevertheless, both certified nurses and student nurses have strong motivation toward learning nursing English, but they also worry about speaking English in 
and outside of class.

Regarding to the frequency and importance of English use for nursing students, based on Lee's (2016) [44] findings, they could be listed as:

1) For reading: the most frequently used of nursing reading tasks are "order sheets", "inspection reports", "consultation sheets", "medication and treatment sheets", and "progress notes" (p. 74).

2) For oral communication: the top five frequently used of listening and speaking tasks are "nursing shift handover", "discussion with medical teams", "case study discussion", "delivering medical instruments", and "reporting patients' conditions" (p. 71).

3) For writing: the most frequently used of nursing writing tasks are "medical and treatment sheets", "T.P.R. sheets", "Kardex writing", "checklists for pre-operation", and "nursing assessment forms" (p. 75).

Lee (2016) [44] also found that student nurses were aware of the importance of English in their nursing practicum and even felt that their familiarity with English might affect the operation of their nursing duties. Hence, student nurses had strong motivation toward English learning, and they would be willing to participate in on-job English training. However, at the same time, they were very anxious about their inadequate English proficiency, especially oral communication skills. So, it was suggested that they should build up self-confidence, try to learn actively, and be aware that "culture is communication and communication is culture" (cited in Wang \& Greenwood, 2015: p. 254) [45], and understand some differences of behaviors and education between Chinese and English-related cultures so as to equip themselves with adequate English skills in the nursing field.

\section{Methodology}

The research methodology included: 1) research design, 2) research questions, 3) sampling of the participants, 4) instrumentation, 5) validity and reliability of the instrument, as well as 6) data collection, procedure and 7) analysis and ethical considerations. They were described below:

\subsection{Research Design}

Together with cluster and convenience sampling, a case study was used for the research methodology. That was because of its being a convenient way of selecting a sample by choosing groups of subjects [46] as well as a bounded system, which was in a particular circumstance and with a particular problem, and also gave readers "space" for their own opinions [47]. The present study aimed to investigate Taiwanese nursing students' English learning behaviors and environmental factors related to their English performance before and after their medical internships, hence, it was appropriate to adopt the method for the study.

\subsection{Research Questions}

The research questions are as follows: 
1) How are Taiwanese nursing students motivated to learn English before and after internships?

2) What strategies do they use more frequently when learning English before and after internships?

3) What are their anxieties about English learning before and after internships?

4) What are the factors related to their English levels before and after internships?

5) What is the correlation among environmental factors, learning behavior, and English levels before and after internships?

6) What are the possible impacts of internship experiences on their English learning behaviors and performance?

\subsection{Sampling of the Participants}

A total of 514 nursing students from five junior colleges in southern Taiwan participated in the study, including 30 male students and 484 female students (in the pretest). They were all fourth grade students arranged by individual schools to fill out questionnaires dealing with their background, motivation, attitude, motivational intensity, strategy use, and anxiety toward English learning. The reason why fourth grade students were chosen as the participants was because they were about to do their internships in the hospitals for one year, and most of them would have no English class afterwards in the junior college period. So, it was supposed to be the right time to investigate their English learning behaviors and English proficiency before they graduated. In addition, most of them were arranged to participate in the posttest after their 1-year internships, including 33 males and 470 females. The subjects of the study were shown in Table 1.

\subsection{Instrumentation}

A fairly large scale self-report survey was used as the research instrument, which was made available monolingual in Chinese, to avoid receiving any false response due to students' misinterpretations of the items, and also as Liu (2015, p. 1875) [48] mentioned that "if we have a group of students who all speak the same first language, we can use a translated form of an instrument-noting". The

Table 1. Subjects of the study in the pretest and the posttest.

\begin{tabular}{|c|c|c|c|c|c|c|c|c|c|c|c|c|c|}
\hline & & \multicolumn{10}{|c|}{ Schools } & \multirow{2}{*}{\multicolumn{2}{|c|}{ total }} \\
\hline & & \multicolumn{2}{|c|}{ School 1} & \multicolumn{2}{|c|}{ School 2} & \multicolumn{2}{|c|}{ School 3} & \multicolumn{2}{|c|}{ School 4} & \multicolumn{2}{|c|}{ School 5} & & \\
\hline & & $\begin{array}{l}\text { pre } \\
\text { test }\end{array}$ & $\begin{array}{c}\text { post } \\
\text { test }\end{array}$ & $\begin{array}{l}\text { pre } \\
\text { test }\end{array}$ & $\begin{array}{l}\text { post } \\
\text { test }\end{array}$ & $\begin{array}{l}\text { pre } \\
\text { test }\end{array}$ & $\begin{array}{l}\text { post } \\
\text { test }\end{array}$ & $\begin{array}{l}\text { pre } \\
\text { test }\end{array}$ & $\begin{array}{l}\text { post } \\
\text { test }\end{array}$ & $\begin{array}{l}\text { pre } \\
\text { test }\end{array}$ & $\begin{array}{l}\text { post } \\
\text { test }\end{array}$ & $\begin{array}{l}\text { pre } \\
\text { test }\end{array}$ & $\begin{array}{l}\text { post } \\
\text { test }\end{array}$ \\
\hline \multirow{2}{*}{ gender } & Male & 7 & 7 & 4 & 8 & 7 & 5 & 6 & 7 & 6 & 6 & 30 & 33 \\
\hline & female & 86 & 85 & 84 & 83 & 113 & 111 & 114 & 111 & 87 & 80 & 484 & 470 \\
\hline \multicolumn{2}{|c|}{ Total } & 93 & 92 & 88 & 91 & 120 & 116 & 120 & 118 & 93 & 86 & 514 & 503 \\
\hline
\end{tabular}


Chinese version questionnaire contained 134 itemized descriptions that were made up of four sections. First section included 6 questions regarding to students' background. Participants were asked to specify their individual demographic information including their gender, previous junior high school, home location, father's education level, mother's education level, and self-evaluation of English proficiency levels of Basic (CEFR A1), Elementary (CEFR A2), between Elementary (CEFR A2) and Intermediate (CEFR B1), Intermediate (CEFR B1) and above.

The remaining sections dealt with 45-item English learning motivation (orientation, attitude, motivational intensity) [3], 50-item strategy [10], and 33-item anxiety [20]. Except for items of Motivational Intensity (items 42 - 51), which were 3-choice questions, the remaining research questions were mainly in five-point Likert scale format, with 1 being Strongly Disagree (SD), 2 being Disagree (D), 3 being No Comment (NC), 4 being Agree (A), and 5 being Strongly Agree (SA). The questionnaire contained 134 itemized descriptions as shown in Table 2.

\subsection{Validity and Reliability of the Instrument}

Measurement is vital in the range of social research contexts. Two major concerns with it are reliability and validity. "What is the reliability of the measuring instrument?" and "What is its validity?" are two questions that researchers want to know. The former means the internal consistency of a test items; while the latter concerns if the instrument is "valid for what and for whom" (Gay, 1992: p. 155) [49].

Validity refers to the extent to which observations and statements are true reflections of reality and measure what is supposed to be measured. It can be

Table 2. Research instrument of the study adopted in the pretest and the posttest.

\begin{tabular}{|c|c|c|c|c|c|c|c|}
\hline Questionnaire/test & Author(s) & year & items & pretest & reliability & posttest & reliability \\
\hline Background & Self-created & 2016 & 06 & Q001-006 & - & Q135-140 & - \\
\hline $\begin{array}{l}\text { Orientations-The } \\
\text { Reasons for } \\
\text { Studying English }\end{array}$ & Gardner, R. C. & 1985 & 16 & Q007-022 & 0.902 & Q141-156 & 0.911 \\
\hline $\begin{array}{l}\text { Attitudes toward } \\
\text { English Learning } \\
\text { and Culture }\end{array}$ & Gardner, R. C. & 1985 & 19 & Q023-041 & 0.886 & Q157-175 & 0.901 \\
\hline $\begin{array}{l}\text { Motivational } \\
\text { Intensity }\end{array}$ & Gardner, R. C. & 1985 & 10 & Q042-051 & 0.804 & Q176-185 & 0.862 \\
\hline $\begin{array}{l}\text { Strategy Inventory of } \\
\text { Foreign Language } \\
\text { Learning }\end{array}$ & Oxford, R. L. & 1990 & 50 & Q052-101 & 0.972 & Q186-235 & 0.976 \\
\hline $\begin{array}{l}\text { Foreign Language } \\
\text { Classroom Anxiety } \\
\text { Scale (FLCAS) }\end{array}$ & Horwitz, et al. & 1986 & 33 & Q102-134 & 0.909 & Q236-268 & 0.918 \\
\hline & & & 128 & Q007-134 & 0.970 & Q141-268 & 0.974 \\
\hline
\end{tabular}


conducted in different ways, such as content validity, criterion-related validity, construct validity, systemic validity, and face validity. In this study, construct validity is used to assess the validity of the measurement instrument because of its best purpose to investigate the theoretical relationship of English achievement to the non-observable learning behaviors. In particular, construct validity is the degree to which a measure is "invented" to explain behavior, especially to explain certain differences between individuals. For example, based on literature review, it is supported that good language learners may have some characteristics in common, such as high language aptitude, strong motivation, favorable attitude, necessary effort, low anxiety, appropriate learning strategy and styles. Hence, the research instrument dealing with learning behaviors is appropriate to be used to explain the validity of the study.

The reliability of the questionnaire was determined by calculating Cronbach's Alpha. Cronbach's Alpha is an appropriate measure of internal consistency when the data are of interval level as most sections of this instrument, except for Section One dealing with students' personal demographic information. The average reliability of this research instrument is $0.804-0.970$. The Alpha value of a "completely perfect" test would reach 1.00 . However, no test can be completely perfect. In addition, Nunnally (1978) [50] recommended "reliabilities of 0.70 or better" for basic research (sited in Panayiotis Panayides, 2013: p. 689) [51]. Hence, the $0.804-0.974$ Alpha value of the test was quite acceptable. In other words, the instrument of the study was favorable reliable.

\subsection{Data Collection, Procedure and Analysis}

After contacting with and being agreed by the five individual teachers in the five schools, the questionnaires were sent to them twice, one was before the second semester of students' fourth academic year, and the other was after the first semester of their fifth semester, to be used as the pretest and the posttest during those nursing students conducting their 1-year practicum in the hospitals. Each teacher helped to choose two classes of nursing students by convenience sampling to serve as participants for the pretest and the same participants for the posttest one year later. All the participants from the five schools helped to fill out the questionnaires and the individual teachers collected them and returned to the researcher. After that, the valid data were tabulated by the SPSS statistical package 17.0, using mean scores, $t$-test for gender difference, between pre-test (before internships) and post-test (after internships), Pearson correlation, as well as Regression analysis for relation and prediction, respectively

In addition to the data receiving from the questionnaire, information about environmental factors relating to English learning of the five participating junior colleges was gathered from the internet of each school. The information included English teachers, English teaching hours per week, grants and activities related to English learning of each individual school, such as using English as the medium of instruction (EMI) and Internationalization at Home (IaH). 


\subsection{Ethical Consideration}

The participating five teachers were informed in advance and helped to explain to the participating five hundred nursing students in the five junior colleges about the nature and purpose of the study. In addition, all participating students were told that the data would not be used for any purpose other than the study, and if they would not like to make known their personal demographic information, they didn't need to sign their names on the questionnaire forms.

\section{Findings and Results}

Findings of the study were described below:

\subsection{Students' Background Information}

Among the nursing participants, more than ninety percent were females, and more than three fourths graduated from public junior high schools. As for their hometown, more than half were from southern Taiwan. Regarding to their parents' educational background, more fathers graduated from colleges (or above) than mothers, while more mothers graduated from senior high schools than fathers. As for students' self-report English proficiency, in average, 63\% - 65\% were Basic (CEFR A1), 21\% - 23\% were Elementary (CEFR A2), 9\% - 10\% were between Elementary (CEFR A2) and Intermediate (CEFR B1), and the rest 2\% $3 \%$ were intermediate (CEFR B1) (and above). In a word, majority of the nursing students were females, most graduated from public junior high, and came from Southern Taiwan; half of their fathers (51\%) and mothers (61\%) graduated from high schools. In addition, many students (64\%) self-reported their English proficiency level was only Basic (CEFR A1), while students "can understand very short, simple texts a single phrase at a time, picking up familiar names, words and basic phrases and reading as required" (http://www.coe.int/, http://www.britchcouncil.org). Students' demographic information was displayed in Table 3.

\subsection{Students English Learning Behaviors before and after the Internships}

In light of nursing students' English learning behaviors before and after their internships, significant differences only existed in students' attitude $(p<0.01)$ and instrumental orientation $(p<0.01)$. After their internships, students had lower means in both attitude and instrumental orientation. In addition, though after the internships, students had lower means in motivation and integrative orientation, and higher means in motivational intensity, strategy use, and anxiety, yet the differences didn't reach any significant levels. The findings were displayed in Table 4.

\subsection{Motivation, Attitude, and Motivational Intensity before and after the Internships}

In general, students had strong motivation $(\mathrm{M}=3.52 / 3.47$ out of 5$)$, positive 
Table 3. Students' personal demographic information in the pretest and posttest.

\begin{tabular}{|c|c|c|c|c|c|c|c|}
\hline \multicolumn{8}{|l|}{ Section One: } \\
\hline I. Personal demographic information & test & $1 \%$ & $2 \%$ & $3 \%$ & $4 \%$ & $5 \%$ & $6 \%$ \\
\hline & pre & 5.81 & 94.2 & & & & \\
\hline 1) Gender, a) Mrale, of remare & post & 6.6 & 93.4 & & & & \\
\hline 2) I graduated from: a) public junior high school, & pre & 85.4 & 6.0 & 8.6 & & & \\
\hline b) private school, c) other & post & 77.6 & 8.2 & 14.3 & & & \\
\hline 3) My hometown is in: & pre & 2.51 & 1.6 & 12.3 & 19.8 & 59.7 & 4.1 \\
\hline $\begin{array}{l}\text { a) The North, b) The North-central, c) The Central, } \\
\text { d) The Central-South, e) The South, } \\
\text { f) The East of Taiwan }\end{array}$ & post & 3.5 & 1.4 & 12.0 & 20.2 & 59.4 & 3.5 \\
\hline 4) My father's education: a) Junior high (and below), & pre & 28.9 & 51.3 & 19.1 & & & \\
\hline b) Senior high, c) College (and above) & post & 23.3 & 51.2 & 25.5 & & & \\
\hline 5) My mother's education: a) Junior high (and below), & pre & 19.1 & 62.8 & 18.1 & & & \\
\hline b) Senior high, c) College (and above) & post & 19.0 & 60.6 & 20.4 & & & \\
\hline $\begin{array}{l}\text { 6) My English level: a) Basic (A1), b) Elementary (A2), } \\
\text { c) between Elementary (A2) and Intermediate (B1), }\end{array}$ & pre & 63.5 & 23.5 & 10.5 & 2.5 & & \\
\hline (4) Intermediate (B1) (and above) & post & 65.5 & 21.8 & 9.8 & 2.9 & & \\
\hline
\end{tabular}

Table 4. Descriptive analysis of students' English learning behaviors before and after their internships.

\begin{tabular}{lccccccc}
\hline & \multicolumn{2}{c}{ participants } & \multicolumn{2}{c}{ pretest } & \multicolumn{2}{c}{ posttest } & \multirow{2}{*}{ sig } \\
\cline { 2 - 6 } & pretest & posttest & Mean & SD & Mean & SD & \\
\hline motivation & 514 & 489 & 3.52 & 0.63 & 3.47 & 0.57 & 0.102 \\
attitude & 514 & 489 & 3.49 & 0.56 & 3.42 & 0.52 & 0.005 \\
Motivational intensity & 514 & 490 & 2.16 & 0.36 & 2.19 & 0.39 & 0.096 \\
instrumental & 514 & 487 & 3.69 & 0.63 & 3.59 & 0.56 & 0.001 \\
integrative & 514 & 490 & 3.36 & 0.71 & 3.35 & 0.65 & 0.863 \\
strategy & 514 & 489 & 3.10 & 0.63 & 3.16 & 0.54 & 0.054 \\
anxiety & 514 & 489 & 3.11 & 0.51 & 3.14 & 0.44 & 0.263 \\
\hline
\end{tabular}

attitude $(\mathrm{M}=3.49 / 3.42$ out of 5$)$, and favorable motivational intensity $(\mathrm{M}=$ 2.16/2.19 out of 3 ) in the pretest (before the internships) and the posttest (after the internships), respectively. However, regarding to students' English learning motivation (instrumental orientation, integrative orientation), attitude, and motivational intensity, the findings revealed that after their 1-year internships, students had lower means in both attitude $(p<0.01)$ and instrumental orientation $(p<0.01)$. In particular, students became less instrumentally motivated after their internships $(p<0.01)$, especially in such items as: "To fulfill a school requirement" ( $p<0.01)$, “To get a better job" $(p<0.01)$, "To make friends with foreign language speakers" $(p<0.01)$, “To be an educated person” $(p<0.05)$, 
"To travel abroad" $(p<0.01)$, and "English seems of great importance today" $(p<0.05)$. On the other hand, students had stronger integrative orientation in the item: "To leave Taiwan and become a member of American society" ( $p<$ 0.05 ) after their internships (in the posttest).

As for attitude, after the internships, students held significantly less positive attitude toward English learning, English culture and English people $(p<0.01)$, especially in such items as: "English is an international language, everyone should learn English" ( $p<0.01)$, "I wish I could speak English fluently" ( $p<$ $0.01)$, "I hope to make friends with English speaking people" $(p<0.01)$, "In addition to English, I want to learn an additional foreign language in the future" ( $p$ $<0.05)$, "I like to have chances to know other country's culture, so I hope to study abroad" ( $p<0.01$ ), "I hope to travel to an English speaking country" ( $p<$ $0.01)$, "I expect to have more practical teaching material for us to learn, because I am not satisfied with the present textbook we use" $(p<0.01)$, "I expect to have teachers who are native speakers of English" $(p<0.01)$, and "I hope to study abroad in the summer or winter vacation" ( $p<0.01)$. Nevertheless, they held more positive attitude toward the item "I enjoy writing diary, letters, or compositions in English" $(p<0.01)$.

Regarding to motivational intensity, after the internships, students seemed to spend more time and effort in such items dealing with: "English homework" ( $p$ $<0.01)$, "actively think about what I have learned in English class:" $(p<0.05)$, "If teacher wanted someone to do an extra English assignment, I would definitely volunteer" ( $p<0.01)$, and "after getting English assignments back, I always read carefully, or rewrite them, correcting my mistakes" $(p<0.05)$.

\subsection{Foreign Language Learning Strategy before and after the Internships}

As Table 5 showed that students used English learning strategies moderately $(\mathrm{M}=$ $3.10-3.16$ out of 5). Among the six types of strategy that students used when learning English, Memory strategy ranked number one $\left(1^{\text {st }}\right)$, followed by Compensation strategy $\left(2^{\text {nd }}\right)$, Metacognitive strategy (3rd), Affective strategy (4th), and they used Cognitive strategy and Social strategy less. Nevertheless, after the

Table 5. Mean and standard deviation of six kinds of strategies before and after the internships.

\begin{tabular}{|c|c|c|c|c|c|c|c|c|c|c|c|c|c|c|}
\hline \multirow{2}{*}{$\begin{array}{l}\text { Kinds of } \\
\text { strategy }\end{array}$} & \multicolumn{2}{|c|}{$\begin{array}{l}\text { Memory } \\
\text { Strategy }\end{array}$} & \multicolumn{2}{|c|}{$\begin{array}{l}\text { Cognitive } \\
\text { Strategy }\end{array}$} & \multicolumn{2}{|c|}{$\begin{array}{c}\text { Compensation } \\
\text { strategy }\end{array}$} & \multicolumn{2}{|c|}{$\begin{array}{c}\text { Metacognitive } \\
\text { Strategy }\end{array}$} & \multicolumn{2}{|c|}{$\begin{array}{l}\text { Affective } \\
\text { strategy }\end{array}$} & \multicolumn{2}{|c|}{$\begin{array}{l}\text { Social } \\
\text { strategy }\end{array}$} & \multicolumn{2}{|c|}{ All } \\
\hline & $\begin{array}{l}\text { pre } \\
\text { test }\end{array}$ & $\begin{array}{l}\text { post } \\
\text { test }\end{array}$ & $\begin{array}{l}\text { pre } \\
\text { test }\end{array}$ & $\begin{array}{l}\text { post } \\
\text { test }\end{array}$ & $\begin{array}{l}\text { pre } \\
\text { test }\end{array}$ & $\begin{array}{l}\text { post } \\
\text { test }\end{array}$ & $\begin{array}{l}\text { pre } \\
\text { test }\end{array}$ & $\begin{array}{l}\text { post } \\
\text { test }\end{array}$ & $\begin{array}{l}\text { Pre } \\
\text { test }\end{array}$ & $\begin{array}{l}\text { post } \\
\text { test }\end{array}$ & $\begin{array}{l}\text { pre } \\
\text { test }\end{array}$ & $\begin{array}{l}\text { post } \\
\text { test }\end{array}$ & $\begin{array}{l}\text { pre } \\
\text { test }\end{array}$ & $\begin{array}{l}\text { post } \\
\text { test }\end{array}$ \\
\hline M & 3.32 & 3.28 & 3.00 & 3.08 & 3.18 & 3.22 & 3.08 & 3.18 & 3.07 & 3.16 & 2.94 & 3.11 & 3.10 & 3.16 \\
\hline SD & 0.68 & 062 & 0.70 & 0.61 & 0.71 & 0.61 & 0.72 & 0.60 & 0.71 & 0.60 & 0.74 & 0.65 & 0.62 & 0.54 \\
\hline $\mathrm{N}$ & 512 & 490 & 507 & 483 & 510 & 484 & 510 & 485 & 508 & 485 & 510 & 483 & 510 & 450 \\
\hline rank & (1) & (1) & (5) & (6) & (2) & (2) & (3) & (3) & (4) & (4) & (6) & (5) & & \\
\hline Sig & \multicolumn{2}{|c|}{0.193} & \multicolumn{2}{|c|}{0.035} & \multicolumn{2}{|c|}{0.653} & \multicolumn{2}{|c|}{0.011} & \multicolumn{2}{|c|}{0.017} & \multicolumn{2}{|c|}{0.000} & \multicolumn{2}{|c|}{0.054} \\
\hline
\end{tabular}


internships, students used more Cognitive strategy $(p<0.05)$, Metacognitive strategy $(p<0.05)$, Affective strategy $(p<0.05)$, and Social strategy $(p<0.01)$ than before. Though there was no significant difference in overall Memory strategy after the internships, yet, students expressed more that they "review English lessons often" after the internships $(p<0.05)$. The same is true to Compensation strategy, while no significant difference was found in overall Compensation strategy, but more students would "make up new words if I do not know the right ones in English" $(p<0.01)$.

The findings of the mean and standard deviation of the six kinds of strategies before and after the internships were displayed in Table 5.

\subsection{Foreign Language Learning Anxiety before and after the Internships}

The findings revealed that students had moderate level of English learning anxiety $(M=3.11-3.14$ out of 5$)$. Similar to some kinds of strategy, not a significant difference was found in overall anxiety after the internships, yet, less students expressed that "I don't worry about making mistakes in English class" ( $p<$ $0.01)$, "I would not be nervous speaking with English native speakers" $(p<0.01)$, and "I feel confident when I speak English in English class" $(p<0.01)$. On the other hand, after the internships, more students expressed that "I wouldn't bother me at all to take more English classes" $(p<0.01)$ and "I feel more tense and nervous when I am speaking in my English class" $(p<0.01)$. The findings were presented in Table 6.

\subsection{Environmental Factors Related to English Learning of the Five Schools}

In Taiwan's five-year junior colleges, the amount of total credits is 220 at least, basically including 12 required credits of English among them. In general, the English courses are arranged in the first two or three years, with 2 or 3 teaching hours per week. To take the five participating schools as example, School 1 (S1) arranged the 12 English credits in the first four semesters for 3 hours per week as 3-3-3-3-0-0-0-0-0-0, while School 2 (S2) added another 4 fours and arranged in the first four semesters for 2 hours per week and the following two semesters for 4 hours per week as 2-2-2-2-4-4-0-0-0-0. As for School 3 (S3), like S1, another 2

Table 6. Differences of anxiety before and after the internships.

\begin{tabular}{|c|c|c|c|c|c|}
\hline \multirow{2}{*}{ Anxiety Items } & \multicolumn{2}{|c|}{ pretest } & \multicolumn{2}{|c|}{ posttest } & \multirow{2}{*}{ Sig } \\
\hline & M & $\mathrm{SD}$ & M & $\mathrm{SD}$ & \\
\hline I don't worry about making mistakes in English class. & 3.13 & 0.96 & 3.01 & 0.82 & 0.006 \\
\hline I would not be nervous speaking with English native speakers. & 3.33 & 1.04 & 2.89 & 0.89 & 0.000 \\
\hline I feel confident when I speak English in English class. & 3.15 & 0.99 & 3.03 & 0.79 & 0.002 \\
\hline I wouldn't bother me at all to take more English classes. & 3.06 & 0.97 & 3.09 & 0.85 & 0.003 \\
\hline I feel more tense and nervous when I am speaking in my English class. & 2.90 & 1.06 & 3.11 & 0.93 & 0.001 \\
\hline
\end{tabular}


hours were added to it, and made it to be 2-2-3-3-2-2 -0-0 -0-0 hours per week in the first 6 semesters. But for School 4 (S4), like S2, another 4 hours were added as 2-2-2-4-2-2-0-0-0-0, for the first 7 semesters per week. Unlike the other four schools, School 5 (S5) also added another 2 hours but it was arranged in the last semester to make it as 3-3-2-2-2-0-0-0-0-2.

Additionally, to increase students' English proficiency of technical and vocational college/university, Taiwan Ministry of Education has been providing grants for Improving Technical and Vocational College/University Students' English Proficiency Program (ITVCSPP) and International Cooperation (IC) and Exchange Program (EP) for years. Among the five participating junior colleges, School 2 (S2) has been granted 12 times (6 ITVCSPP, 2 IC and 4 EP), followed by School 3 (S3), 10 times (ITVCSPP), School 5 (S5), 9 times (ITVCSPP), School 4 (S4), 5 times (3 IC and 2 EP), and School 1 (S1), 1 time.

Another factor which couldn't be underestimated was the role of English teachers. Among the five participating schools, only School 2 has Applied English Department (and Applied Japanese Department) with 13 full time English teachers, while School 3 formerly had Applied English Department (changed as Tourism Department in 2009) with 8 full time English teachers, and School 5 has Language Center years with 7 full time English teachers. With sufficient full time teacher professional resources and school's support, it could explain why the three schools were able to hold and be granted much more English related activities successfully and bring about some possible consequences about students' English learning behaviors and even English levels.

The findings of English learning environments among the five participating schools were presented in Table 7.

Table 7. English learning environments among the five participating schools.

\begin{tabular}{|c|c|c|c|c|c|c|c|c|c|c|c|c|c|c|c|c|c|c|c|c|c|c|}
\hline \multirow{2}{*}{ 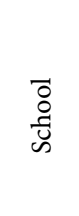 } & \multicolumn{3}{|c|}{ Subjects 2015} & \multicolumn{3}{|c|}{$\begin{array}{c}\text { All nursing } \\
\text { students } 2014\end{array}$} & \multicolumn{3}{|c|}{ All students 2014} & \multirow{2}{*}{ 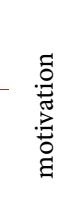 } & \multirow{2}{*}{ 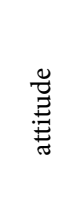 } & \multirow{2}{*}{ 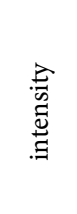 } & \multirow{2}{*}{ 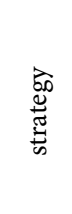 } & \multirow{2}{*}{ 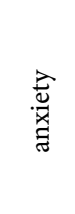 } & \multirow{2}{*}{ 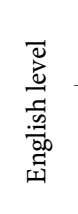 } & \multicolumn{3}{|c|}{ English courses/hrs } & \multirow[t]{2}{*}{ teacher } & \multirow{2}{*}{ tũ } & \multirow{2}{*}{ 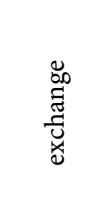 } & \multirow{2}{*}{$\begin{array}{l}\text { 苟 } \\
\text { 매 }\end{array}$} \\
\hline & $\sum_{\Sigma}^{\frac{0}{\pi}}$ & 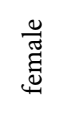 & స & ๕ี & 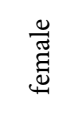 & न & $\frac{\dddot{\Xi}}{\text { ङ }}$ & 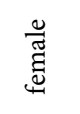 & न & & & & & & & $\begin{array}{l}\vec{\Xi} \\
\stackrel{\Xi}{\Xi} \\
\stackrel{\Xi}{\Xi}\end{array}$ & 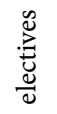 & न & & & & \\
\hline S1 & 7 & 86 & 93 & 55 & 346 & 401 & 268 & 584 & 852 & 3.57 & 3.42 & 2.22 & 3.05 & 3.12 & 1.34 & 12 & 2 & 14 & 2 & & & 1 \\
\hline S2 & 5 & 84 & 89 & 224 & 1868 & 2092 & 1936 & 5095 & 7031 & 3.60 & 3.53 & 2.23 & 3.14 & 3.18 & 1.54 & 14 & 2 & 16 & 13 & 1 & $\mathrm{C}, \mathrm{J}, \mathrm{U}$ & 12 \\
\hline S3 & 7 & 113 & 120 & 180 & 1818 & 1993 & 1660 & 4685 & 6345 & 3.56 & 3.52 & 2.09 & 3.13 & 3.15 & 1.41 & 12 & 2 & 14 & 8 & 2 & & 10 \\
\hline S4 & 6 & 114 & 120 & 86 & 1170 & 1256 & 156 & 1853 & 2009 & 3.48 & 3.52 & 2.11 & 3.12 & 3.07 & 1.38 & 14 & 2 & 16 & 3 & & & 5 \\
\hline S5 & 6 & 87 & 93 & 152 & 1939 & 2091 & 446 & 3373 & 3819 & 3.44 & 3.45 & 2.17 & 3.05 & 3.03 & 1.97 & 12 & 2 & 14 & 7 & 3 & & 9 \\
\hline Sig & & & & & & & & & & 0.852 & 0.372 & 0.024 & 0.596 & 0.499 & 0.000 & & & & & & & \\
\hline all & 31 & 484 & 515 & 697 & 7141 & 7833 & 4466 & 18,590 & 20,056 & 3.53 & 3.49 & 2.15 & 3.10 & 3.11 & 1.51 & 12.8 & 2.8 & 14.8 & & & & \\
\hline High & & & & & & & & & & 5 & 5 & 3 & 5 & 5 & 4 & 14 & 2 & 16 & & & & \\
\hline Low & & & & & & & & & & 1 & 1 & 1 & 1 & 1 & 1 & 12 & 2 & 14 & & & & \\
\hline
\end{tabular}

${ }^{* 1}$-School 2 (S2) has Applied English Department \& Applied Japanese Department; ${ }^{* 2}$-School 3 (S3) has Tourism Department (change from formerly Applied English Department in 2009); ${ }^{* 3}$-School 5 (S5) has Language Center; ${ }^{*}$ Exchange countries-A: Australia, C: Canada, J: Japan, U: USA. 


\subsection{Gender Differences in Learning Behaviors and English Levels before and after the Internships}

It was found that gender differences existed in motivational intensity, strategy, and English levels before the internships, while male students had higher means than females $(p<0.05)$, but after the internships, gender differences only existed in English levels, the same, males had higher means than females $(p<0.01)$. Nevertheless, after the internships, in addition to motivation, instrumental orientation, and anxiety, with which females had higher means, the findings revealed that female students tended to have higher means in integrative orientation, attitude, strategy, and anxiety than male students, though the differences didn't reach a significant level.

The findings of gender differences in English learning behaviors and English levels before and after the internships were shown in Table 8 .

Table 8. Gender differences in learning behaviors and English levels before and after the internships.

\begin{tabular}{|c|c|c|c|c|c|c|c|c|c|}
\hline & & \multicolumn{2}{|c|}{$\mathrm{N}$} & \multicolumn{2}{|c|}{ Mean } & \multicolumn{2}{|c|}{$\mathrm{SD}$} & \multicolumn{2}{|c|}{ Sig } \\
\hline & & pretest & posttest & pretest & posttest & pretest & posttest & pretest & posttest \\
\hline \multirow{3}{*}{ 1) Motivation } & male & 28 & 32 & 3.50 & 3.36 & 0.77 & 0.81 & \multirow{3}{*}{0.802} & \multirow{3}{*}{0.239} \\
\hline & female & 475 & 457 & 3.53 & 3.49 & 0.62 & 0.55 & & \\
\hline & total & 503 & 489 & 3.53 & 3.48 & 0.63 & 0.57 & & \\
\hline \multirow{3}{*}{$\begin{array}{l}\text { 2) Instrumental } \\
\text { Orientation }\end{array}$} & male & 29 & 32 & 3.66 & 3.43 & 0.73 & 0.75 & \multirow{3}{*}{0.764} & \multirow{3}{*}{0.078} \\
\hline & female & 479 & 457 & 3.70 & 3.61 & 0.63 & 0.54 & & \\
\hline & total & 508 & 489 & 3.69 & 3.60 & 0.63 & 0.56 & & \\
\hline \multirow{3}{*}{$\begin{array}{l}\text { 3) Integrative } \\
\text { Orientation }\end{array}$} & male & 29 & 32 & 3.43 & 3.30 & 0.91 & 0.90 & \multirow{3}{*}{0.638} & \multirow{3}{*}{0.581} \\
\hline & female & 480 & 458 & 3.37 & 3.37 & 0.70 & 0.63 & & \\
\hline & total & 509 & 490 & 3.37 & 3.36 & 0.71 & 0.65 & & \\
\hline \multirow{3}{*}{$\begin{array}{l}\text { 4) Motivational } \\
\text { Intensity }\end{array}$} & male & 30 & 32 & 2.31 & 2.30 & 0.37 & 0.46 & \multirow{3}{*}{0.019} & \multirow{3}{*}{0.106} \\
\hline & female & 484 & 458 & 2.15 & 2.19 & 0.36 & 0.38 & & \\
\hline & total & 514 & 490 & 2.15 & 2.20 & 0.36 & 0.39 & & \\
\hline \multirow{3}{*}{ 5) Attitude } & male & 30 & 32 & 3.62 & 3.27 & 0.68 & 0.70 & \multirow{3}{*}{0.211} & \multirow{3}{*}{0.109} \\
\hline & female & 483 & 455 & 3.48 & 3.43 & 0.55 & 0.50 & & \\
\hline & total & 513 & 487 & 3.49 & 3.42 & 0.56 & 0.52 & & \\
\hline \multirow{3}{*}{ 6) Strategy } & male & 30 & 31 & 3.34 & 3.15 & 0.92 & 0.79 & \multirow{3}{*}{0.031} & \multirow{3}{*}{0.891} \\
\hline & female & 465 & 445 & 3.08 & 3.16 & 0.60 & 0.54 & & \\
\hline & total & 495 & 476 & 3.10 & 3.16 & 0.62 & 0.52 & & \\
\hline \multirow{3}{*}{ 7) Anxiety } & male & 29 & 32 & 2.95 & 3.13 & 0.66 & 0.54 & \multirow{3}{*}{0.083} & \multirow{3}{*}{0.882} \\
\hline & female & 475 & 444 & 3.12 & 3.14 & 0.50 & 0.44 & & \\
\hline & total & 504 & 476 & 3.11 & 3.14 & 0.51 & 0.44 & & \\
\hline \multirow{3}{*}{ 8) English levels } & male & 30 & 32 & 1.80 & 1.87 & 0.99 & 1.07 & \multirow{3}{*}{0.043} & \multirow{3}{*}{0.005} \\
\hline & female & 480 & 458 & 1.50 & 1.47 & 0.76 & 0.75 & & \\
\hline & total & 510 & 490 & 1.51 & 1.50 & 0.78 & 0.78 & & \\
\hline
\end{tabular}




\subsection{Students' English Learning Behaviors and English Levels among the Five Participating Schools before and after the Internships}

Regarding to English learning behaviors and English levels among the five participating nursing schools, before the internships, there were significant differences on motivational intensity $(p<0.05)$, especially School 2 had higher mean than School $3(p<0.05)$, and English levels $(p<0.01)$, in which School 2 had higher mean than other four schools $(p<0.01)$. However, after the internships, a significant difference only existed in Motivational intensity $(p<0.01)$, in which School 1 had higher mean than School $4(p<0.01)$.

Furthermore, before students' internships, among the five participating schools, it was found that School 2 ranked second in English levels, and number one in all of the five factors of English learning behaviors (i.e. motivation, attitude, motivational intensity, strategy, and anxiety), though only the difference of motivational intensity reached a significant difference $(p<0.05)$. In addition, as for School 5, except for motivational intensity, it had the lowest mean of motivation, attitude, strategy, and anxiety, though the differences didn't reach significant levels, yet School 5 had the highest English levels $(p<0.01)$. Nevertheless, after the internships, in light of English levels, there was no significant difference among the five participating schools, though School 5 still kept the best $\left(1^{\text {st }}\right)$, yet School 2 dropped from the second down to next to the last $\left(5^{\text {th }}\right)$ which needs to be paid attention to.

The findings of students' English learning behaviors and English levels among the five participating schools were presented in Table 9.

\subsection{Summary of Students' English Learning Behavior and English Levels among the Five Schools}

To summarize, before the 1-year internships, regarding to students' English learning motivation, attitude, motivational intensity, strategy, anxiety, and English levels, among the five participating schools, School 1 ranked (2) (5) (2) (4) (3) (5), while School 2 ranked (1) (1) (1) (1) (1) (2), School 3 ranked (3) (2) (5) (2) (2) (4), School 4 ranked (4) (2) (4) (3) (4) (3), and School 5 ranked (5) (4) (3) (4) (5) (1), respectively. To take School 2 and School 5 as examples, it seemed that students of School 2 had best English learning motivation, attitude, motivational intensity and strategy, but also highest anxiety, and second best English level, while School 5, students had moderate motivation, attitude, motivational intensity and strategy, but lowest anxiety, and best English levels.

But after their internships, School 1 ranked (3) (4) (1) (2) (3) (4), while School 2 ranked (1) (1) (2) (1) (2) (5), School 3 ranked (5) (5) (4) (5) (1) (2), School 4 ranked (2) (2) (5) (4) (4) (3), and School 5 ranked (4) (3) (3) (3) (5) (1), for students' English learning motivation, attitude, motivational intensity, strategy, anxiety, and English level, respectively.

The findings of students' English learning behaviors and English levels among the five schools before and after the internships were presented in Table 10 and Table 11, respectively. 
Table 9. Students' English learning behaviors and English levels among the five participating schools before and after the internships.

\begin{tabular}{|c|c|c|c|c|c|c|c|c|c|}
\hline & & \multicolumn{2}{|c|}{$\mathrm{N}$} & \multicolumn{2}{|c|}{ Mean } & \multicolumn{2}{|c|}{ SD } & \multicolumn{2}{|c|}{ Sig } \\
\hline & & pretest & posttest & pretest & posttest & pretest & posttest & pretest & posttest \\
\hline \multirow{6}{*}{ 1) Motivation } & S1 & 91 & 79 & 3.57 & 3.44 & 0.68 & 0.61 & \multirow{6}{*}{0.852} & \multirow{6}{*}{0.272} \\
\hline & S2 & 86 & 91 & 3.60 & 3.57 & 0.67 & 0.64 & & \\
\hline & S3 & 116 & 116 & 3.56 & 3.42 & 0.56 & 0.53 & & \\
\hline & S4 & 118 & 118 & 3.48 & 3.52 & 0.62 & 0.53 & & \\
\hline & S5 & 92 & 85 & 3.44 & 3.43 & 0.64 & 0.56 & & \\
\hline & total & 503 & 489 & 3.53 & 3.48 & 0.63 & 0.57 & & \\
\hline \multirow{6}{*}{ 2) Attitude } & S1 & 93 & 79 & 3.42 & 3.39 & 0.60 & 0.56 & \multirow{6}{*}{0.372} & \multirow{6}{*}{0.403} \\
\hline & S2 & 88 & 90 & 3.53 & 3.47 & 0.55 & 0.52 & & \\
\hline & S3 & 120 & 114 & 3.52 & 3.37 & 0.55 & 0.45 & & \\
\hline & S4 & 120 & 118 & 3.52 & 3.46 & 0.54 & 0.55 & & \\
\hline & S5 & 92 & 86 & 3.45 & 3.40 & 0.55 & 0.53 & & \\
\hline & total & 513 & 487 & 3.49 & 3.42 & 0.56 & 0.52 & & \\
\hline \multirow{6}{*}{ 3) Intensity } & S1 & 93 & 79 & 2.22 & 2.33 & 0.40 & 0.49 & \multirow{6}{*}{0.024} & \multirow{6}{*}{0.004} \\
\hline & S2 & 88 & 91 & 2.23 & 2.22 & 0.39 & 0.38 & & \\
\hline & S3 & 120 & 116 & 2.09 & 2.16 & 0.35 & 0.39 & & \\
\hline & S4 & 120 & 118 & 2.11 & 2.12 & 0.34 & 0.34 & & \\
\hline & S5 & 93 & 86 & 2.17 & 2.19 & 0.30 & 0.32 & & \\
\hline & total & 514 & 490 & 2.15 & 2.20 & 0.36 & 0.39 & & \\
\hline \multirow{6}{*}{ 4) Strategy } & S1 & 91 & 76 & 3.05 & 3.18 & 0.69 & 0.53 & \multirow{6}{*}{0.596} & \multirow{6}{*}{0.602} \\
\hline & S2 & 85 & 89 & 3.14 & 3.23 & 0.67 & 0.63 & & \\
\hline & S3 & 116 & 112 & 3.13 & 3.11 & 0.52 & 0.40 & & \\
\hline & S4 & 111 & 114 & 3.12 & 3.15 & 0.63 & 0.56 & & \\
\hline & S5 & 92 & 85 & 3.05 & 3.15 & 0.62 & 0.60 & & \\
\hline & total & 495 & 476 & 3.10 & 3.16 & 0.62 & 0.54 & & \\
\hline \multirow{6}{*}{ 5) Anxiety } & S1 & 92 & 74 & 3.12 & 3.17 & 0.62 & 0.48 & \multirow{6}{*}{0.499} & \multirow{6}{*}{0.566} \\
\hline & S2 & 87 & 89 & 3.18 & 3.17 & 0.60 & 0.49 & & \\
\hline & S3 & 118 & 112 & 3.15 & 3.18 & 0.47 & 0.37 & & \\
\hline & S4 & 115 & 117 & 3.07 & 3.11 & 0.41 & 0.40 & & \\
\hline & S5 & 92 & 84 & 3.03 & 3.09 & 0.44 & 0.51 & & \\
\hline & total & 504 & 476 & 3.11 & 3.14 & 0.51 & 0.44 & & \\
\hline \multirow{6}{*}{ 6) English levels } & S1 & 93 & 79 & 1.34 & 1.44 & 0.63 & 0.72 & \multirow{6}{*}{0.000} & \multirow{6}{*}{0.550} \\
\hline & S2 & 88 & 91 & 1.54 & 1.42 & 0.80 & 0.79 & & \\
\hline & S3 & 117 & 116 & 1.41 & 1.51 & 0.58 & 0.71 & & \\
\hline & S4 & 119 & 118 & 1.38 & 1.50 & 0.67 & 0.85 & & \\
\hline & S5 & 93 & 86 & 1.97 & 1.61 & 1.03 & 0.82 & & \\
\hline & total & 510 & 490 & 1.53 & 1.50 & 0.78 & 0.78 & & \\
\hline
\end{tabular}


Table 10. Summary of students' English learning behaviors and English levels among the five schools before the internships.

\begin{tabular}{|c|c|c|c|c|c|c|c|c|c|c|c|c|c|c|c|c|c|c|c|}
\hline & \multirow{2}{*}{ School } & \multicolumn{3}{|c|}{ Motivation } & \multicolumn{3}{|c|}{ attitude } & \multicolumn{3}{|c|}{ intensity } & \multicolumn{3}{|c|}{ strategy } & \multicolumn{3}{|c|}{ Anxiety } & \multicolumn{3}{|c|}{ English level } \\
\hline & & M & SD & Rank & M & SD & $\mathrm{R}$ & M & SD & Rank & M & $\mathrm{SD}$ & Rank & M & SD & Rank & M & SD & Rank \\
\hline 1 & School 1 & 3.57 & 0.68 & (2) & 3.42 & 0.60 & (5) & 2.22 & 0.40 & (2) & 3.05 & 0.69 & (4) & 3.12 & 0.62 & (3) & 1.34 & 0.63 & (5) \\
\hline 2 & School 2 & 3.60 & 0.67 & (1) & 3.53 & 0.55 & (1) & 2.23 & 0.39 & (1) & 3.14 & 0.67 & (1) & 3.18 & 0.60 & (1) & 1.54 & 0.80 & (2) \\
\hline 3 & School 3 & 3.56 & 0.56 & (3) & 3.52 & 0.55 & (2) & 2.09 & 0.35 & (5) & 3.13 & 0.52 & (2) & 3.15 & 0.47 & (2) & 1.41 & 0.58 & (4) \\
\hline 4 & School 4 & 3.48 & 0.62 & (4) & 3.52 & 0.54 & (2) & 2.11 & 0.34 & (4) & 3.12 & 0.63 & (3) & 3.07 & 0.41 & (4) & 1.38 & 0.67 & (3) \\
\hline \multirow[t]{5}{*}{5} & School 5 & 3.44 & 0.64 & (5) & 3.45 & 0.55 & (4) & 2.17 & 0.30 & (3) & 3.05 & 0.62 & (4) & 3.03 & 0.44 & (5) & 1.97 & 1.03 & (1) \\
\hline & Average & 3.53 & 0.63 & & 3.49 & 0.56 & & 2.15 & 0.36 & & 3.10 & 0.62 & & 3.11 & 0.51 & & 1.51 & 0.78 & \\
\hline & Sig & \multicolumn{3}{|c|}{0.852} & \multicolumn{3}{|c|}{0.372} & \multicolumn{3}{|c|}{0.024} & \multicolumn{3}{|c|}{0.596} & \multicolumn{3}{|c|}{0.499} & \multicolumn{3}{|c|}{0.000} \\
\hline & Max & \multicolumn{3}{|c|}{5} & \multicolumn{3}{|c|}{5} & \multicolumn{3}{|c|}{3} & \multicolumn{3}{|c|}{5} & \multicolumn{3}{|c|}{5} & \multicolumn{3}{|c|}{4} \\
\hline & Min & \multicolumn{3}{|c|}{1} & \multicolumn{3}{|c|}{1} & \multicolumn{3}{|c|}{1} & \multicolumn{3}{|c|}{1} & \multicolumn{3}{|c|}{1} & \multicolumn{3}{|c|}{1} \\
\hline
\end{tabular}

Table 11. Summary of students' English learning behaviors and English levels among the five schools after the internships.

\begin{tabular}{|c|c|c|c|c|c|c|c|c|c|c|c|c|c|c|c|c|c|c|c|}
\hline & \multirow{2}{*}{ School } & \multicolumn{3}{|c|}{ Motivation } & \multicolumn{3}{|c|}{ attitude } & \multicolumn{3}{|c|}{ intensity } & \multicolumn{3}{|c|}{ strategy } & \multicolumn{3}{|c|}{ Anxiety } & \multicolumn{3}{|c|}{ English level } \\
\hline & & M & SD & Rank & M & SD & $\mathrm{R}$ & M & SD & Rank & M & SD & Rank & M & SD & Rank & M & SD & Rank \\
\hline 1 & School 1 & 3.44 & 0.61 & (3) & 3.39 & 0.56 & (4) & 2.33 & 0.49 & (1) & 3.18 & 0.53 & (2) & 3.173 & 0.48 & (3) & 1.44 & 0.72 & (4) \\
\hline 2 & School 2 & 3.57 & 0.64 & (1) & 3.47 & 0.52 & (1) & 2.22 & 0.38 & (2) & 3.23 & 0.63 & (1) & 3.174 & 0.49 & (2) & 1.42 & 0.79 & (5) \\
\hline 3 & School 3 & 3.42 & 0.53 & (5) & 3.37 & 0.45 & (5) & 2.16 & 0.39 & (4) & 3.11 & 0.40 & (5) & 3.18 & 0.47 & (1) & 1.51 & 0.71 & (2) \\
\hline 4 & School 4 & 3.52 & 0.53 & (2) & 3.46 & 0.55 & $(2)$ & 2.12 & 0.39 & (5) & 3.151 & 0.56 & (4) & 3.11 & 0.41 & (4) & 1.50 & 0.85 & (3) \\
\hline \multirow[t]{5}{*}{5} & School 5 & 3.43 & 0.56 & (4) & 3.40 & 0.53 & (3) & 2.19 & 0.34 & (3) & 3.152 & 0.60 & (3) & 3.09 & 0.44 & (5) & 1.61 & 0.82 & (1) \\
\hline & Average & 3.48 & 0.57 & & 3.42 & 0.52 & & 2.20 & 0.39 & & 3.16 & 0.54 & & 3.14 & 0.51 & & 1.50 & 0.78 & \\
\hline & Sig & \multicolumn{3}{|c|}{0.167} & \multicolumn{3}{|c|}{0.403} & \multicolumn{3}{|c|}{0.105} & \multicolumn{3}{|c|}{0.574} & \multicolumn{3}{|c|}{0.814} & \multicolumn{3}{|c|}{0.872} \\
\hline & Max & \multicolumn{3}{|c|}{5} & \multicolumn{3}{|c|}{5} & \multicolumn{3}{|c|}{3} & \multicolumn{3}{|c|}{5} & \multicolumn{3}{|c|}{5} & \multicolumn{3}{|c|}{4} \\
\hline & Min & \multicolumn{3}{|c|}{1} & \multicolumn{3}{|c|}{1} & \multicolumn{3}{|c|}{1} & \multicolumn{3}{|c|}{1} & \multicolumn{3}{|c|}{1} & \multicolumn{2}{|c|}{1} & \\
\hline
\end{tabular}

\subsection{Factors Related to English Learning Behaviors and English Levels before and after the Internships}

By regression analysis, it was found that before the internships, among environmental factors (English hours, English teachers, and English grants), English learning behaviors (motivation, attitude, motivational intensity, strategy, and anxiety), and English levels, factors related to integrative orientation and motivational intensity were both English teachers $(t=2.144$, sig $=0.032)$ and English grants, negatively $(t=-2.006$, Sig $=0.045)$. The same, factors related to motivational intensity were both English teachers $(t=3.250$, sig $=0.001)$ and English grants, negatively $(t=-3.199$, sig $=0.001)($ see Table 12$)$.

As after the internships, findings revealed that English hours was related to both instrumental orientation $(t=2.349$, sig $=0.019)$ and overall motivation $(t=$ 2.012 , sig $=0.045)$. Furthermore, factors related to motivational intensity were English teachers $(t=3.386$, sig $=0.001)$ and English grants, negatively $(t=$ -3.618 , sig $=0.000)($ see Table 13). 
Table 12. Regression analysis of environmental factors predicting English levels and learning behaviors before the internships.

\begin{tabular}{|c|c|c|c|c|c|c|c|c|c|c|c|c|c|c|c|c|}
\hline \multirow{3}{*}{ Variables } & \multicolumn{6}{|c|}{ motivation } & \multirow{2}{*}{\multicolumn{2}{|c|}{ attitude }} & \multirow{2}{*}{\multicolumn{2}{|c|}{ intensity }} & \multirow{2}{*}{\multicolumn{2}{|c|}{ strategy }} & \multirow{2}{*}{\multicolumn{2}{|c|}{ anxiety }} & \multirow{2}{*}{\multicolumn{2}{|c|}{ English levels }} \\
\hline & \multicolumn{2}{|c|}{ instrumental } & \multicolumn{2}{|c|}{ integrative } & \multicolumn{2}{|c|}{ motivation } & & & & & & & & & & \\
\hline & $t$ & sig & $t$ & sig & $t$ & sig & $t$ & sig & $t$ & sig & $t$ & sig & $t$ & sig & $t$ & sig \\
\hline (constant) & 8.784 & 0.000 & 7.408 & 0.000 & 8.370 & 0.000 & 7.826 & 0.000 & 9.061 & 0.000 & 6.124 & 0.000 & 8.899 & 0.000 & 4.258 & 0.000 \\
\hline English hours & -0.316 & 0.752 & -0.403 & 0.687 & -0.227 & 0.821 & 1.187 & 0.236 & -0.096 & 0.923 & 0.917 & 0.360 & -0.121 & 0.904 & -1.768 & 0.078 \\
\hline English teacher & 1.066 & 0.287 & 2.144 & 0.032 & 1.573 & 0.116 & -0.474 & 0.636 & 3.250 & 0.001 & -0.145 & 0.885 & -1.572 & 0.117 & -0.857 & 0.392 \\
\hline English grants & -0.898 & 0.402 & -2.006 & 0.045 & -1.387 & 0.166 & -0.791 & 0.429 & -3.199 & 0.001 & 0.336 & 0.737 & -1.190 & 0.234 & 1.936 & 0.053 \\
\hline
\end{tabular}

${ }^{* *} p<0.01,{ }^{*} p<0.05$.

Table 13. Regression analysis of environmental factors predicting English levels and learning behaviors after the internships.

\begin{tabular}{|c|c|c|c|c|c|c|c|c|c|c|c|c|c|c|c|c|}
\hline \multirow{3}{*}{ Variables } & \multicolumn{6}{|c|}{ motivation } & \multirow{2}{*}{\multicolumn{2}{|c|}{ attitude }} & \multirow{2}{*}{\multicolumn{2}{|c|}{ intensity }} & \multirow{2}{*}{\multicolumn{2}{|c|}{ strategy }} & \multirow{2}{*}{\multicolumn{2}{|c|}{ anxiety }} & \multirow{2}{*}{\multicolumn{2}{|c|}{ English levels }} \\
\hline & \multicolumn{2}{|c|}{ instrumental } & \multicolumn{2}{|c|}{ integrative } & \multicolumn{2}{|c|}{ motivation } & & & & & & & & & & \\
\hline & $t$ & sig & $t$ & sig & $t$ & sig & $t$ & sig & $t$ & sig & $t$ & sig & $t$ & sig & $t$ & $\operatorname{sig}$ \\
\hline (constant) & 6.773 & 0.000 & 5.965 & 0.000 & 6.695 & 0.000 & 7.750 & 0.000 & 10.22 & 0.000 & 7.641 & 0.000 & 10.439 & 0.000 & 3.173 & 0.000 \\
\hline English hours & 2.349 & 0.019 & 1.534 & 0.126 & 2.012 & 0.045 & 1.630 & 0.104 & -1.813 & 0.070 & 0.573 & 0.567 & -0.504 & 0.614 & -0.506 & 0.613 \\
\hline English teacher & 0.199 & 0.842 & 0.845 & 0.398 & 0.572 & 0.568 & 0.281 & 0.779 & 3.386 & 0.001 & 1.345 & 0.179 & -0.994 & 0.321 & -1.189 & 0.235 \\
\hline English grants & -0.069 & 0.945 & -0.864 & 0.388 & -0.450 & 0.653 & -0.282 & 0.778 & -3.618 & 0.000 & -1.23 & 0.218 & -0.794 & 0.428 & 1.236 & 0.217 \\
\hline
\end{tabular}

Additionally, by Regression analysis, the findings showed that in the pretest, English learning behaviors predicting English levels were motivational intensity $(t=2.519$, sig $=0.012)$, strategy $(t=1.998$, sig $=0.046)$, and anxiety, negatively $(t$ $=-2.519$, sig $=0.012$, while in the posttest, English learning behaviors predicting English levels were integrative orientation $(t=2.450$, sig $=0.015)$, attitude, negatively $(t=-2.192$, sig $=0.029)$, motivational intensity $(t=2.724$, sig $=$ $0.007)$, and strategy $(t=2.936$, sig $=0.003)$ (see Table 14$)$.

Findings of regression analysis of environmental factors (English hour, English teacher, and English grant), and English learning behaviors (motivation, attitude, motivational intensity, strategy, and anxiety) predicting English levels before and after the internships were presented in Tables 12-14, respectively and Figures 1-3 as well.

\subsection{Correlation among Environmental Factors, Students' Learning Behaviors and Their English Levels before and after the Internships}

Before and after the internships, both findings revealed that in light of environmental factors, English hours, English teachers, and English grants were correlated to one another $(p<0.01)$ and $(p<0.01)$, respectively. In addition, English teachers and English grants were correlated to each other $(p<0.01)$.

As for English learning behaviors, motivation was correlated to attitude $(p<$ $0.01)$, motivational intensity $(p<0.01)$, strategy $(p<0.01)$, and anxiety $(p<0.01)$ 


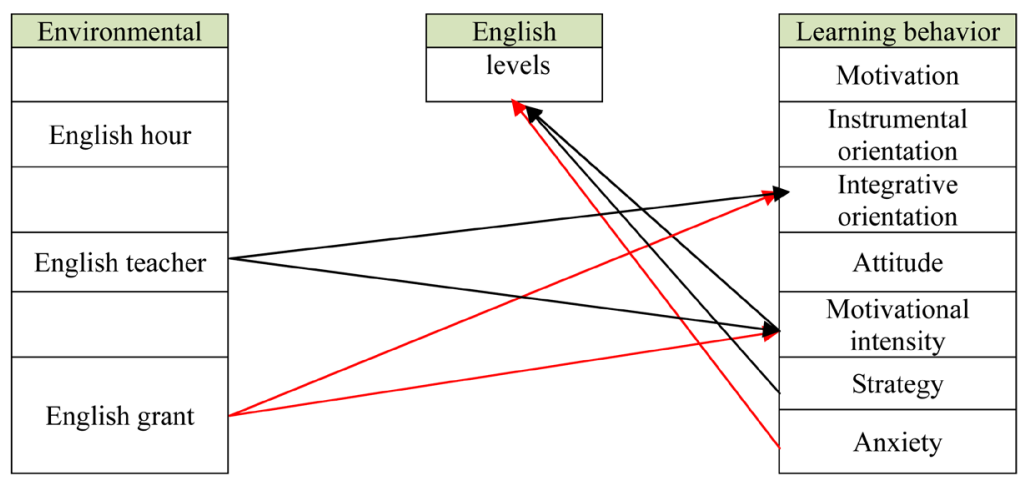

Note. English teacher was related to Integrative orientation $(t=2.144, \operatorname{sig}=0.032)$ English teacher was related to motivational intensity $(t=3.250, \mathrm{sig}=0.001)$ English grant was related to Integrative orientation, negatively $(t=-2.006, \mathrm{sig}=0.045)$

English grant was related to motivational intensity, negatively $(t=-3.199, \mathrm{sig}=0.001)$

Motivational intensity was related to English levels $(t=2.519$, sig $=0.012)$

Strategy was related to English levels $(t=1.998$, sig $=0.046)$

Anxiety was related to English levels, negatively $(t=-2.519$, sig $=0.012)$

Figure 1. Factors related to English levels before the internships.

\begin{tabular}{|c|c|c|}
\hline Environmental & English \\
\hline English hour & levels & $\begin{array}{c}\text { Instrumental } \\
\text { orientation }\end{array}$ \\
\hline English teacher & $\begin{array}{l}\text { Integrative } \\
\text { orientation }\end{array}$ \\
\hline English grant & $\begin{array}{c}\text { Attitude } \\
\text { Motivational } \\
\text { intensity }\end{array}$ \\
\hline Strategy \\
\hline Anxiety
\end{tabular}

Note. English hour was related to Motivation $(t=2.012, \operatorname{sig}=0.045)$

English hour was related to Instrumental orientation $(t=2.349$, sig $=0.019)$

English teacher was related to motivational intensity $(t=3.386$, sig $=0.001)$

English grant was related to motivational intensity, negatively $(t=-3.618, \operatorname{sig}=0.000)$

Integrative orientation was related to English levels $(t=2.450, \mathrm{sig}=0.015)$

Attitude was related to English levels, negatively $(t=-2.192$, sig $=0.007)$

Motivational intensity was related to English levels $(t=2.724$, sig $=0.015)$

Strategy was related to English levels $(t=2.936$, sig $=0.003)$

Figure 2. Factors related to English levels after the internships.

Table 14. Regression analysis of English learning behavior predicting English levels before and after the internships.

\begin{tabular}{ccccc}
\hline \multirow{2}{*}{ Variable } & \multicolumn{2}{c}{ English levels-pretest } & \multicolumn{2}{c}{ English levels-posttest } \\
\cline { 2 - 4 } & $t$ & Sig & $t$ & sig \\
\hline (constant) & 3.709 & 0.000 & 3.709 & 0.000 \\
Motivation & -1.138 & 0.256 & -1.138 & 0.256 \\
instrumental orientation & 0.181 & 0.856 & -0.699 & 0.485 \\
Integrative orientation & -1.302 & 0.194 & 2.450 & $\mathbf{0 . 0 1 5}$ \\
Attitude & 0.341 & 0.734 & -2.192 & $\mathbf{0 . 0 2 9}$ \\
motivational intensity & 2.519 & $\mathbf{0 . 0 1 2}$ & 2.724 & $\mathbf{0 . 0 0 7}$ \\
Strategy & 1.998 & $\mathbf{0 . 0 4 6}$ & 2.936 & $\mathbf{0 . 0 0 3}$ \\
Anxiety & -2.519 & $\mathbf{0 . 0 1 2}$ & -0.938 & 0.349 \\
\hline
\end{tabular}

${ }^{* *} p<0.01,{ }^{*} p<0.05$. 


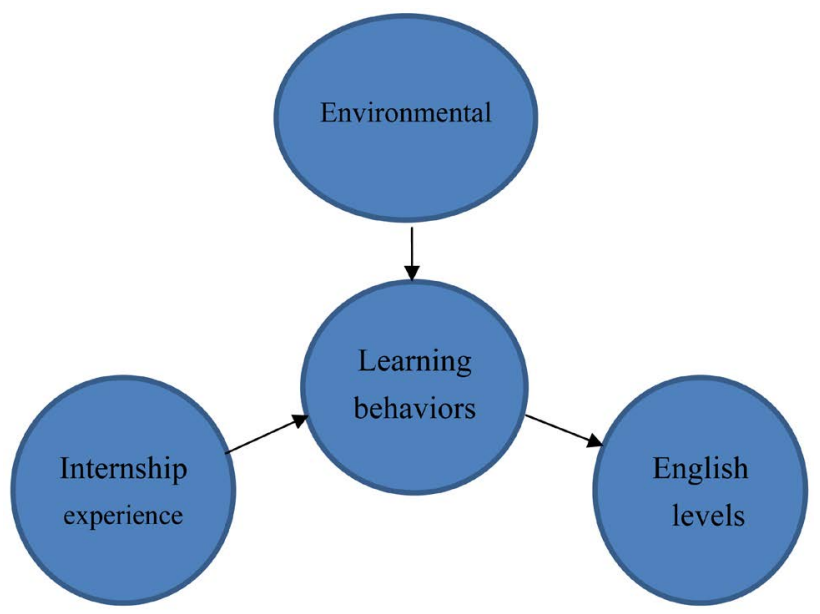

Figure 3. Correlation among environmental factor, learning behaviors, internship experience, and English levels.

negatively; while attitude was correlated to motivational intensity $(p<0.01)$, strategy $(p<0.01)$, and anxiety $(p<0.01)$ negatively. Additionally, motivational intensity was correlated to strategy $(p<0.01)$, anxiety $(p<0.05)$, and English levels $(p<0.01)$. Furthermore, strategy was found to be correlated to anxiety $(p<$ $0.01)$ negatively and English level $(p<0.01)$, while anxiety was found to be negatively correlated to all motivation $(p<0.01)$ negatively, attitude $(p<0.01)$, motivational intensity $(p<0.05)$, and strategy $(p<0.01)$ as well as English level $(p<$ $0.01)$. And English level was shown to be correlated to English teachers $(p<$ $0.05)$, English grants $(p<0.01)$, motivational intensity $(p<0.01)$, strategy $(p<$ $0.01)$, and anxiety $(p<0.05)$ negatively.

Nevertheless, some differences were found in environmental factors and students' learning behaviors after their 1-year internships. First, after their internships, another two significant correlations were added, including the correlation between English hours and motivation $(p<0.05)$ as well as between motivation and English levels $(p<0.01)$. Second, one of the correlations was increased, which was the correlation between motivational intensity and anxiety $(p<0.01)$. Third, after the internships, three of the correlations dealing with the English levels before the internships were not existing, including the correlation between English levels and English teachers $(p<0.05)$, English grants $(p<0.01)$, and anxiety $(p<0.05)$ negatively.

Findings of the correlation among environmental factors, students' learning behavior, and their English levels before and after the internships were shown in Table 15 and Table 16 and Figure 3.

\subsection{Summary and the Answers to the Research Questions}

In the study, among the participating nursing students in the pretest and posttest (before and after internships), most of them were females (93\% - 94\%), graduated from public junior high schools $(78 \%-85 \%)$, came from the southern part of Taiwan (59\% - 60\%), and more than half of their parents graduated from high 
Table 15. Correlation among environmental factors, students' learning behavior, and their English levels before the internships.

\begin{tabular}{|c|c|c|c|c|c|c|c|c|c|c|}
\hline & & $\begin{array}{c}\text { English } \\
\text { hours }\end{array}$ & $\begin{array}{l}\text { English } \\
\text { teachers }\end{array}$ & $\begin{array}{c}\text { English } \\
\text { grants }\end{array}$ & Motivation & attitude & intensity & strategy & anxiety & $\begin{array}{c}\text { English } \\
\text { level }\end{array}$ \\
\hline \multirow[t]{3}{*}{ English hours } & P Pearson & 1 & $0.352\left(^{* *}\right)$ & $\left.0.269{ }^{* *}\right)$ & -0.001 & 0.048 & 0.013 & 0.039 & -0.010 & -0.072 \\
\hline & Sig & & 0.000 & 0.000 & 0.975 & 0.277 & 0.767 & 0.381 & 0.824 & 0.105 \\
\hline & $\mathrm{N}$ & 601 & 601 & 601 & 503 & 513 & 514 & 495 & 504 & 510 \\
\hline \multirow[t]{3}{*}{ English teachers } & Pearson & $0.352(* *)$ & 1 & $0.911\left(^{* *}\right)$ & 0.029 & 0.036 & 0.049 & 0.026 & -0.050 & $0.105\left(^{*}\right)$ \\
\hline & Sig & 0.000 & & 0.000 & 0.516 & 0.416 & 0.268 & 0.571 & 0.261 & 0.018 \\
\hline & $\mathrm{N}$ & 601 & 601 & 601 & 503 & 513 & 514 & 495 & 504 & 510 \\
\hline \multirow[t]{3}{*}{ English grants } & Pearson & $0.269\left(^{* *}\right)$ & $0.911\left(^{* *}\right)$ & 1 & 0.008 & 0.048 & -0.019 & 0.030 & -0.032 & $\left.0.123{ }^{* *}\right)$ \\
\hline & Sig & 0.000 & 0.000 & & 0.856 & 0.277 & 0.669 & 0.503 & 0.469 & 0.005 \\
\hline & $\mathrm{N}$ & 601 & 601 & 601 & 503 & 513 & 514 & 495 & 504 & 510 \\
\hline \multirow{3}{*}{ motivation } & Pearson & -0.001 & 0.029 & 0.008 & 1 & $0.791\left(^{* *}\right)$ & $\left.0.336{ }^{* *}\right)$ & $0.537\left(^{* *}\right)$ & $\left.-0.185{ }^{* *}\right)$ & 0.034 \\
\hline & Sig & 0.975 & 0.516 & 0.856 & & 0.000 & 0.000 & 0.000 & 0.000 & 0.444 \\
\hline & $\mathrm{N}$ & 503 & 503 & 503 & 503 & 502 & 503 & 484 & 493 & 499 \\
\hline \multirow[t]{3}{*}{ Attitude } & Pearson & 0.048 & 0.036 & 0.048 & $\left.0.7911^{* *}\right)$ & 1 & $\left.0.394{ }^{(* *}\right)$ & $0.642\left(^{* *}\right)$ & -0.280 & 0.074 \\
\hline & Sig & 0.277 & 0.416 & 0.277 & 0.000 & & 0.000 & 0.000 & 0.000 & 0.096 \\
\hline & $\mathrm{N}$ & 513 & 513 & 513 & 502 & 513 & 513 & 494 & 503 & 509 \\
\hline \multirow[t]{3}{*}{ intensity } & Pearson & 0.013 & 0.049 & -0.019 & $0.336\left(^{* *}\right)$ & $0.394{ }^{(* *)}$ & 1 & $0.596\left(^{* *}\right)$ & $-0.114\left(^{*}\right)$ & $\left.0.206{ }^{* *}\right)$ \\
\hline & Sig & 0.767 & 0.268 & 0.669 & 0.000 & 0.000 & & 0.000 & 0.010 & 0.000 \\
\hline & $\mathrm{N}$ & 514 & 514 & 514 & 503 & 513 & 514 & 495 & 504 & 510 \\
\hline \multirow[t]{3}{*}{ strategy } & Pearson & 0.039 & 0.026 & 0.030 & $0.537(* *)$ & $0.642\left(^{* *}\right)$ & $0.596\left(^{* *}\right)$ & 1 & $-0.306\left(^{* *}\right)$ & $\left.0.163^{* *}\right)$ \\
\hline & Sig & 0.381 & 0.571 & 0.503 & 0.000 & 0.000 & 0.000 & & 0.000 & 0.000 \\
\hline & $\mathrm{N}$ & 495 & 495 & 495 & 484 & 494 & 495 & 495 & 488 & 491 \\
\hline \multirow[t]{3}{*}{ Anxiety } & Pearson & -0.010 & -0.050 & -0.032 & $\left.-0.185{ }^{(* *}\right)$ & $\left.-0.280{ }^{* \star}\right)$ & $-0.114\left(^{\star}\right)$ & $-0.306\left(^{\star *}\right)$ & 1 & $-0.093\left(^{*}\right)$ \\
\hline & Sig & 0.824 & 0.261 & 0.469 & 0.000 & 0.000 & 0.010 & 0.000 & & 0.038 \\
\hline & $\mathrm{N}$ & 504 & 504 & 504 & 493 & 503 & 504 & 488 & 504 & 500 \\
\hline \multirow[t]{3}{*}{ English level } & Pearson & -0.072 & $0.105\left(^{*}\right)$ & $\left.0.123{ }^{* *}\right)$ & 0.034 & 0.074 & $\left.0.206^{(* *}\right)$ & $0.163(* *)$ & $-0.093\left(^{*}\right)$ & 1 \\
\hline & Sig & 0.105 & 0.018 & 0.005 & 0.444 & 0.096 & 0.000 & 0.000 & 0.038 & \\
\hline & $\mathrm{N}$ & 510 & 510 & 510 & 499 & 509 & 510 & 491 & 500 & 510 \\
\hline
\end{tabular}

${ }^{* *} p<0.01,{ }^{*} p<0.05$.

schools. In addition, only $34 \%$ - 36\% of their self-reported English level was Elementary (CEFR A2) and above, which was the appropriate level that junior high school graduates were supposed to have (see Table 3 ).

As for English learning behaviors, environmental factors, and English levels, the participating nursing students had favorable English learning behaviors and environmental supports, but many students' English proficiency was not satisfactory. In fact, about $64 \%$ - 66\% of the students lacked appropriate English proficiency levels to meet the job-market language skills (for senior high school graduates with CEFR B1 supposed to have). 
Table 16. Correlation among environmental factors, students' learning behavior, and their English levels after the internships.

\begin{tabular}{|c|c|c|c|c|c|c|c|c|c|c|}
\hline & & $\begin{array}{l}\text { English } \\
\text { hours }\end{array}$ & $\begin{array}{l}\text { English } \\
\text { teachers }\end{array}$ & $\begin{array}{l}\text { English } \\
\text { grants }\end{array}$ & Motivation & attitude & intensity & strategy & anxiety & $\begin{array}{c}\text { English } \\
\text { level }\end{array}$ \\
\hline \multirow[t]{3}{*}{ English hours } & P Pearson & 1 & $0.306(* *)$ & $0.267(* \star)$ & $0.099\left(^{*}\right)$ & 0.078 & -0.062 & 0.039 & -0.013 & -0.032 \\
\hline & Sig & & 0.000 & 0.000 & 0.029 & 0.087 & 0.172 & 0.395 & 0.771 & 0.486 \\
\hline & $\mathrm{N}$ & 601 & 601 & 601 & 489 & 487 & 490 & 476 & 476 & 490 \\
\hline \multirow[t]{3}{*}{ English teachers } & Pearson & $0.306(* *)$ & 1 & $0.932(* *)$ & 0.036 & 0.016 & -0.008 & 0.031 & -0.029 & -0.011 \\
\hline & Sig & 0.000 & & 0.000 & 0.426 & 0.725 & 0.859 & 0.496 & 0.525 & 0.816 \\
\hline & $\mathrm{N}$ & 601 & 601 & 601 & 489 & 487 & 490 & 476 & 476 & 490 \\
\hline \multirow[t]{3}{*}{ English grants } & Pearson & $0.267\left(^{* *}\right)$ & $0.932(* *)$ & 1 & 0.022 & 0.007 & -0.064 & 0.007 & -0.015 & 0.012 \\
\hline & Sig & 0.000 & 0.000 & & 0.631 & 0.882 & 0.157 & 0.886 & 0.751 & 0.788 \\
\hline & $\mathrm{N}$ & 601 & 601 & 601 & 489 & 487 & 490 & 476 & 476 & 490 \\
\hline \multirow[t]{3}{*}{ motivation } & Pearson & $0.099\left(^{*}\right)$ & 0.036 & 0.022 & 1 & $0.790\left(^{* *}\right)$ & $0.283\left({ }^{* *}\right)$ & $0.551\left(^{* *}\right)$ & $-0.280\left(^{* *}\right)$ & $0.135\left(^{* *}\right)$ \\
\hline & Sig & 0.029 & 0.426 & 0.631 & & 0.000 & 0.000 & 0.000 & 0.000 & 0.003 \\
\hline & $\mathrm{N}$ & 489 & 489 & 489 & 489 & 486 & 489 & 475 & 475 & 489 \\
\hline \multirow[t]{3}{*}{ Attitude } & Pearson & 0.078 & 0.016 & 0.007 & $0.790\left(^{* *}\right)$ & 1 & $0.292\left(^{* *}\right)$ & $\left.0.640{ }^{* *}\right)$ & $-0.340\left(^{* \star}\right)$ & 0.076 \\
\hline & Sig & 0.087 & 0.725 & 0.882 & 0.000 & & 0.000 & 0.000 & 0.000 & 0.096 \\
\hline & $\mathrm{N}$ & 487 & 487 & 487 & 486 & 487 & 487 & 473 & 473 & 487 \\
\hline \multirow[t]{3}{*}{ intensity } & Pearson & -0.062 & -0.008 & -0.064 & $0.283(* *)$ & $0.292\left(^{* *}\right)$ & 1 & $0.516(* *)$ & $-0.130\left(^{* *}\right)$ & $0.223\left(^{* *}\right)$ \\
\hline & Sig & 0.172 & 0.859 & 0.157 & 0.000 & 0.000 & & 0.000 & 0.005 & 0.000 \\
\hline & $\mathrm{N}$ & 490 & 490 & 490 & 489 & 487 & 490 & 476 & 476 & 490 \\
\hline \multirow[t]{3}{*}{ strategy } & Pearson & 0.039 & 0.031 & 0.007 & $0.551(* *)$ & $0.640\left(^{* *}\right)$ & $0.516\left(^{* *}\right)$ & 1 & $-0.417\left(^{* *}\right)$ & $0.210^{(* *)}$ \\
\hline & Sig & 0.395 & 0.496 & 0.886 & 0.000 & 0.000 & 0.000 & & 0.000 & 0.000 \\
\hline & $\mathrm{N}$ & 476 & 476 & 476 & 475 & 473 & 476 & 476 & 466 & 476 \\
\hline \multirow[t]{3}{*}{ Anxiety } & Pearson & -0.013 & -0.029 & -0.015 & $\left.-0.280{ }^{\star *}\right)$ & $-0.340\left(^{\star *}\right)$ & $-0.130\left(^{\star *}\right)$ & $-0.417(* *)$ & 1 & -0.021 \\
\hline & Sig & 0.771 & 0.525 & 0.751 & 0.000 & 0.000 & 0.010 & 0.000 & & 0.649 \\
\hline & $\mathrm{N}$ & 476 & 476 & 476 & 475 & 473 & 476 & 466 & 476 & 476 \\
\hline \multirow[t]{3}{*}{ English level } & Pearson & -0.032 & -0.011 & 0.012 & $0.135(* *)$ & 0.076 & $0.223(* *)$ & $0.210(* *)$ & -0.021 & 1 \\
\hline & Sig & 0.486 & 0.816 & 0.788 & 0.003 & 0.096 & 0.000 & 0.000 & 0.649 & \\
\hline & $\mathrm{N}$ & 490 & 490 & 490 & 489 & 487 & 490 & 476 & 476 & 490 \\
\hline
\end{tabular}

${ }^{* *} p<0.01,{ }^{*} p<0.05$

Regarding to gender differences, before their internships, male students were stronger in motivational intensity $(p<0.05)$, strategy, and English levels $(p<$ $0.05)$ than females; though after their internships, males still outperformed in English levels $(p<0.01)$, yet females had higher means in English learning motivation, instrumental orientation, integrative orientation, attitude, strategy, and even anxiety than males, though the differences didn't reach a significant level.

Furthermore, among the five participating schools, before the internships, significant differences existed in motivational intensity $(p<0.05)$ and English levels $(p<0.01)$. Comparatively, School 2 had the highest motivational intensity, 
followed by School 1, School 5, School 4, and School 3, but School 5 had the highest English level, followed by School 2, School 3, School 4, and School 1. However, after the internships, a significant difference only existed in motivational intensity $(p<0.01)$, while School 1 had the highest motivational intensity, followed by School 2, School 5, School 3, and School 4. Though after the internships, there was no significant difference in English levels among the five participating schools, yet, the fact that School 2 ranked down from the second $\left(2^{\text {nd }}\right)$ before internships to next to the last $\left(4^{\text {th }}\right)$ after the internships needs to be paid attention to.

\section{Discussions, Implications, Limitations of the Study, and Suggestions for Further Research}

Discussions, implications, limitations of the study, and suggestions for further research were described as follows:

\subsection{Discussions and Implications}

In Taiwan, globalization has brought about a new society and more than $2.7 \%$ of the whole Taiwanese population are foreigners now (Taiwan National Immigration Agency). With the increasing number of aging and diverse foreign patient population in the society, access to health care will expand and the need will increase for more competent and diverse nursing graduates with satisfactory English proficiency. Based on the finding of the study, it showed that Taiwanese nursing students were with strong motivation, positive attitude, and favorable motivational intensity, the same as Yang, et al. reported (2015) [5]. In addition, they used English learning strategies moderately and had moderate level of anxiety. On the other hand, schools tried best to provide sufficient environmental supports of English teaching hours, teachers, and grants related to English learning.

However, the findings also revealed that more than half of the nursing students $(63 \%-65 \%)$ self-reported that their English level was only CEFR A1 (Breakthrough/ Basic), while 21\% - 23\% was CEFR A2 (Waystage/Elementary), and the rest $12 \%$ - 16\% was higher. Based on the CEFR Skill Descriptors

(http://www.britishcouncil.org/), it seemed that many Taiwanese nursing students' English proficiency was not satisfactory to reach the job-related language levels yet, and would lead to what Yang (2011) [43] mentioned that "the majority of clinical nurses in Taiwan are inadequately prepared to communicate with foreign clients or use English when delivering nursing care services" (p. 99).

Why did Taiwanese schools spend so much time and effort in improving students' English proficiency, and students were also highly motivated to learn English, yet the results still came out like that? Based on the present study, findings revealed that in addition to environmental factors, students' internships experience brought about some changes in their English learning behaviors, and relevant to English levels (see Figure 3). In other words, both environmental factors and students' internships experience were predictive to nursing students' 
English learning behaviors, and led to their English levels at the end.

First, regarding to environmental factors, the finding supported what Gardner (1990) [52] mentioned that the environmental language-relevant variables tended to play an important role in influencing students' English learning process and learning outcome. In the present study, all the three factors of English hours, English teachers, and English grants were all relevant to students' English learning behaviors led to English levels before and after their internships positively (English hours and English teachers) or negatively (English grants) (see Figures 1-3). Especially English teachers were found to be related to students' motivational intensity $(p<0.05)$ and led to English levels $(p<0.01)$ both before and after their internships (see Figure $1 \&$ Figure 2). Consequently, in order to increase students' English proficiency, to improve the quality and quantity of English teachers seemed to be the priority. More importantly, English hours were also predictive to students' motivation $(p<0.01)$ and instrumental orientation $(p<0.05)$ after their internships. Hence, it was strongly suggested that schools, on one hand, try to provide more teaching hours of English (including Nursing English) in required and/or elective courses; on the other hand, conduct a balanced arrangement of English scope and sequence in every semester (even during the internship periods, on-line instruction can be an option), instead of placing most emphases on the first 2 - 3 years, to help students have equal chances to "contact" with English regularly.

Second, as for students' English learning behaviors, motivational intensity and strategy were relevant to English levels before and after the internships, while anxiety was found to be negatively related to English levels before the internships $(p<0.01)$, Additionally, after the internships, integrative orientation was relevant to English levels $(p<0.05)$, and attitude was related to English levels, negatively $(p<0.01)$. The results that strategy use was found to be related to English levels was consistent with other studies, such as Hou, et al.'s (2014) [7]. Consequently, together with memory strategy and compensation strategy, such less frequently used strategies as social strategy should be encouraged or trained, especially for female students, who were found to use less strategies than males $(p<0.01)$. Nevertheless, the findings were inconsistent with some studies indicating that females used more strategies than males [12] [16]. The possible explanation might be due to the imbalance of participating nursing students between males and females (6\% vs $94 \%$ ). Furthermore, since in the field of nursing, females play a major part, especially in the society with increasing number of diverse foreign patient population, female nurses' influences were very crucial. However, in the study, female students were found to be with less integrative orientation than males $(p<0.01)$. So, it is strongly suggested that female students be motivated to learn English more integratively, as Gardner (1985) [3] declared that learners with an integrative orientation were more interested in learning the language, had favorable attitudes about the language community and a general openness toward the other groups of people, more importatnly, integratively motivated learners tended to determine long-term success in for- 
eign language learning.

Another possible explanation was relevant to students' internship experience while English was used in nursing. As student nurses in their practicum period, in addition to facing the increasing number of international patients and family or caregivers, they need to use English in interaction mainly with medical crews. However, according to Lee (2016) [44], not only student nurses but also certified nurses are weaker in productive skills (speaking and writing) than receptive skills (listening and reading) though they have strong motivation and positive attitude toward learning nursing English. Regarding to reading, student nurses have to know medical terminology and medication use, including "Order Sheets", "Inspection Reports", etc. As for oral communication, they need to use English, especially during the nursing shift handover. In addition, during physician rounds, they need to listen to what physicians said, including the communication using professional vocabulary between physicians and nurses, and adopting commonly used words between the physicians and international patients or caregivers [44]. As for writing, it is the least used among the four skills in nursing English, though the more frequently used in nursing writing tasks were "Medical and Treatment Sheets" and "T.P.R. Sheets" [44]. Under such demanding circumstances and pressures, in addition to nursing professional needs, student nurses have to apply their nursing English knowledge and skills to the clinical settings. Hence, student nurses claimed that "English plays an important role in their practicum and ...their familiarity with English might affect the operation of their nursing duties" (Lee, 2016: p. 84) [44], and "insufficient personal ability" became the top source of students' practice anxiety and stress (Su \& Kuo, 1993: p. 175) [41], while "unfamiliar with medical records and terminology" was the second stressor (Sheu, Lin, \& Hwang, 2001: p. 238) [42], so they would be "willing to have on-job English training" (Lee, 2016: p. 106) [44]. In the present study, findings also revealed that the internships experience brought about some changes in the nursing students' English learning behaviors, such as: becoming less instrumentally motivated $(p<0.01)$ (while integratively motivated learners tend to determine long-time success in foreign language learning); and having higher means in motivational intensity and strategy use, though the differences didn't reach significant levels (Table 4). On the other hand, after the internships, except that they "enjoy writing diary, letters, or composition in English" ( $p<$ 0.01 ), students tended to hold less positive attitude toward English learning ( $p<$ 0.01 ), and have higher mean in anxiety, though the difference didn't reach a significant difference (Table 4), yet students' lower attitude and higher anxiety after the internships still need to be paid attention.

Furthermore, some findings of negative factors in the study should not be underestimated. One was students' anxiety about English learning. Like other studies [9] [20] [53], anxiety was found to be negatively related to English levels. Findings of the study showed that students worried most about the consequences of failing the class, other students' better performance, and having not prepared in advance. Hence, it is suggested that teachers provide diversified 
evaluation, less competitive atmosphere of learning, and enough time for students to prepare in advance. Another finding of negative factor in the study was that students' attitude toward English became negatively relevant to English levels after their internships $(p<0.01)$. Is it possible that was the negative effect of anxiety, stress, and frustration on their attitude interfering with English learning and outcome? Again, it is suggested that schools, teachers, and certified nurses encourage students to learn actively, help them build up self-confidence and develop positive attitude toward English learning.

The other finding of negative factor in the study was schools being granted for holding English related activities and programs. For the past ten years, School 2 and School 3 were granted 12 times and 10 times to hold English activities, respectively, such as Internationalization at Home (IaH), English as the Medium of Instruction (EMI), and many other English programs granted by Information Center for International Cooperation and Exchange (ICICE) (see 2.4). The findings of the study seemed to be inconsistent with that of others with positive impacts of EMI, identity, and study-abroad [32] [40] [54]. On the contrary, findings of the study showed that School 2 students, together with more English teaching hours, had the highest anxiety; while School 3 students were with the lowest motivational intensity, which led to English levels (see Table 9 and Figure 1). The same, it was suggested that both School 2 and School 3 try to investigate students' attitude toward holding more English related activities and programs expecting to find out the possible explanation of the negative impacts on students' English levels. Lastly, some implications were provided for each participating school (and/or for other schools with similar situations):

School 1 students: Help them to develop more positive attitude toward English learning, for example, helping them to be aware of the importance of English in education and career, and train them to use more strategies when learning English (in the study, School 1 students were found to be with favorable motivation, motivational intensity and anxiety, but lower attitude and strategy use, as well as lowest English level).

School 2 students: Help them to decrease their anxieties about English learning seemed to be the priority, especially in creating a less competitive learning environment for them (almost $47 \%$ of them agreed or strongly agreed that they always felt that the other students spoke English better than they did). In addition, as mentioned earlier, it was suggested that the school investigate students' attitude toward applying for grants for more English related activities and programs to figure out if it was the possible reason for their high anxiety (in the study, School 2 students were found to be all with highest motivation, attitude, motivational intensity, and anxiety, but second to highest English level).

School 3 students: Helping them to cultivate the habits of spending more time and effort to actively think about what they had learned in English class, and become more serious about dealing with English assignment (in the study, School 3 students were found to have favorable motivation, attitude, and anxiety, but lowest motivational intensity and second to lowest English level). 
School 4 students: Help them to strengthen their motivation and motivational intensity (in the study, School 4 students were found to be with favorable attitude, strategy use, anxiety and English level, but lower in motivation and motivational intensity).

School 5 students: Help them to develop stronger motivation, more positive attitude, and use more strategy, though they had the lowest anxiety but the highest English, in particular, helping them to be aware of the importance of English for a better job and for the current society (in the study, School 5 students were found to be with lower motivation, attitude, strategy use, but lowest anxiety, and highest English level).

\subsection{Limitations of the Study and Suggestions for Further Research}

Limitations of the study and suggestions for further research included:

1) This study was conducted using questionnaires about Taiwanese nursing students' English learning motivation, strategy, and anxiety. The questionnaires are self-reporting instruments and reflect reporters' perception and preferences. In particular, Likert-style scales don't capture the full range of responses, making different contexts appear more similar [55]. Therefore, the results of this study were limited to the willingness and seriousness of the participants to complete and return the survey to the researcher. Hence, in the further research, the interview method will be suggested to use both quality and quantity research method.

2) This study was limited to Taiwanese nursing students' English learning, in particular, samples selected from five out of 12 junior colleges having nursing departments in Taiwan. Hence, the findings of the study may not be representative of all nursing students in Taiwan. Therefore, in the future research, it should consider to include samples from other 7 junior colleges.

3) In the study, students' English proficiency was only based on students' self-evaluation of their levels. Consequently, it is strongly suggested that students be arranged to take an English proficiency test for their real English scores instead of just accepting their reported English levels as the present study. Furthermore, the information of frequency and importance of English language use in students' internships were adopted from Lee (2016) [44], future study should include the target participants' internships experience of their own.

4) More importantly, based on the findings, why some schools were granted to hold English related activities and programs but didn't bring about students' favorable motivational intensity and English levels as expected. Hence, further study should be done to investigate students' attitude toward both school's curriculum design and applying for more grants to hold more English related activities and programs.

\section{Acknowledgements}

The author deeply appreciates the participating five teachers and more than five hundred nursing students for their valuable contribution to the study. 


\section{References}

[1] Gardner, R.C. and Lambert, W.E. (1959) Motivational Variables in Second Language Acquisition. Canadian Journal of Psychology, 13, 266-272.

https://doi.org/10.1037/h0083787

[2] Clement, R., Major, L., Gardner, R.C. and Smythe, P.C. (1977) Attitudes and Motivation in Second Language Acquisition: An Investigation of Fontario Francophones. Working Papers on Bilingualism, 12, 1-20.

[3] Gardner, R.C. (1985) Social Psychology and Second Language Learning: The Role of Attitude and Motivation. Edward Arnold, Baltimore, Maryland.

[4] Titone, R. (1990) A Psycho-Sociolinguistic Perspective in EFL Learning: The Role of Attitude a Dynamic Factor. Paper Presented at The World Congress of Applied Linguistics, Sponsored by the International Association of Applied Linguistics, 9th, Thessaloniki, Greece, 15-21 April 1990. ERIC Document Resume, ED 326-073.

[5] Yang, M.-T. and Cheng, H.-Y. (2015) An Investigation of Taiwanese EFL Nursing Students' English Learning Motivation, Attitude, and Achievement. Contemporary Social Sciences, 24, 31-40.

[6] Cheng, H.-Y. (2005) An Investigation of Military School Freshmen's Motivation and English Achievement. Whampo Journal, 49, 245-258.

[7] Hou, Y.-A., Hou, Y.-J., Chung, W.-Y. and Cheng, H.-Y. (2014) Learning Styles, Strategy Use, and English Performance-A Case Study of Taiwanese EFL College Students. The International Journal of Learner Diversity and Identities, 21, 1-11.

[8] Hou, Y.A., Lee, F.M., Hou, Y.J., Chung, W.Y. and Cheng, H.Y. (2012) The Impacts of Teachers' Beliefs on Students' Anxiety about Foreign Language Learning: The East and the West. The International Journal of the Humanities, 9, 245-260.

[9] Cheng, H.-Y., Hou, Y.-J., Hou, Y.-A. and Chung, W.-Y. (2010) Gender Differences in Multiple Intelligences, Learning Behavior and English Performance. The International Journal of the Humanities, 8, 255-270.

[10] Oxford, R.L. (1990) Language Learning Strategies: What Every Teacher Should Know. Heinle \& Heinle, Boston.

[11] Oxford, R.L. (1992) Who Are Our Students? A Synthesis of Foreign and Second Language Research on Individual Differences. TESL Canada Journal, 9, 30-49. https://doi.org/10.18806/tesl.v9i2.602

[12] Wu, K.-H. (2010) The Relationship between Language Learners' Anxiety and Learning Strategy in the CLT Classroom. International Education Studies, 3, 174-191. https://doi.org/10.5539/ies.v3n1p174

[13] Rubin, J. (1981) Study of Cognitive Processes in Second Language Learning. Applied Linguistics, 11, 117-131. https://doi.org/10.1093/applin/II.2.117

[14] Dreyer, C. and Oxford, R.L. (1996) Learning Strategies and Other Predictors of ESL Proficiency among Afrikaans Speakers in South Africa. In: Oxford, R.L., Ed., Language Learning Strategies around the World: Cross-Cultural Perspectives, University of Hawaii, Second Language Teaching \& Curriculum Center, Honolulu, 61-74.

[15] Green, L.M. and Oxford, R.L. (1995) A Closer Look at Learning Strategies, L2 Proficiency, and Gender. TESOL Quarterly, 29, 261-297. https://doi.org/10.2307/3587625

[16] Hsu, Y.L. (2007) Elementary School EFL Students' Learning Style Preferences and Strategy Use and Their Relationship with the Students' English Learning Achievement. Unpublished Master's Thesis, Providence University, Taichung, Taiwan. 
[17] Rossi-Le, L. (1989) Perceptual Learning Style Preferences and Their Relationship to Language Learning Strategies in Adult Students of English as a Second Language. Unpublished Doctoral Dissertation, Drake University, Des Moines, Iowa.

[18] Wittrock, M., Ed. (1977) Learning and Instruction. McCutchan, Berkely.

[19] Scovel, T. (1978) The Effect of Affect on Foreign Language Learning: A Review of the Anxiety Research. Language Learning, 28, 129-142. https://doi.org/10.1111/j.1467-1770.1978.tb00309.x

[20] Horwitz, E.K., Horwitz, M.B. and Cope, J. (1986) Foreign Language Classroom Anxiety. The Modern Language Journal, 70, 125-132. https://doi.org/10.1111/j.1540-4781.1986.tb05256.x

[21] Horwitz, E.K. \& Young, D.J. (1991) Preface. In: Horwitz, E.K. and Young, D.J., Eds., Language Anxiety: From Theory and Research to Classroom Implications, Prentice Hall. Englewood Cliffs, xii-xiv.

[22] Tobias, S. (1986) Anxiety and Cognitive Processing of Instruction. In: Schwarzer, R., Ed., Self-Related Cognition in Anxiety and Motivation, Erlbaum, Hillsdale, 35-54.

[23] MacIntyre, P.D. (1995) How Does Anxiety Affect Second Language Learning? A Reply to Sparks and Ganschow. The Modern Language Journal, 79, 90-99. https://doi.org/10.1111/j.1540-4781.1995.tb05418.x

[24] Albert, R. and Habo, R.N. (1960) Anxiety in Academic Achievement Situations. Journal of Abnormal and Social Psychology, 10, 207-215. https://doi.org/10.1037/h0045464

[25] Gardner, R.C. and MacIntyre, P.D. (1992) A Student's Contributions to Second-Language Learning. Part I: Cognitive Variables. Language Teaching, 25, 211-220. https://doi.org/10.1017/S026144480000700X

[26] Trylong, V.L. (1987) Aptitude, Attitudes, and Anxiety: A Study of Their Relationships to Achievement in the Foreign Language Classroom. Dissertation of Purdue University.

[27] Chapelle, C. and Jamieson, J. (1986) Computer-Assisted Language Learning as a Predictor of Success in Acquiring English as a Second Language. TESOL Quarterly, 20, 27-46. https://doi.org/10.2307/3586387

[28] Hou, Y.-A. (2009) An Investigation of Perceptual Learning Style Preferences, Language Learning Strategy use, and English Achievement-A Case Study of Taiwanese EFL Student. Unpublished Doctoral Dissertation of La Sierra University.

[29] Chan, R.L. (2007) Context and Impact of Medium of Instruction on Attitudes, Motivation and Academic Performance: Secondary School Children in Hong Kong. Unpublished Master's Thesis, Durham University. http://etheses.dur.ac.uk/2851/

[30] Chang, Y.Y. (2010) English-Medium Instruction for Subject Course in Tertiary Education: Reactions from Taiwanese Undergraduate Students. Taiwan International ESP Journal, 2, 55-84.

[31] Chen, Y.-L. and Kraklow, D. (2015) Taiwanese College Students' Motivation and Engagement for English Learning in the Context of Internationalization at Home: A Comparison of Students in EMI and Non-EMI Programs. Journal of Studies in International Education, 19, 46-64. https://doi.org/10.1177/1028315314533607

[32] Lo, Y. (2010) The Challenge of EMI from the Perspective of Higher Education Internationalization. Journal of Kaohsiung University of Technology, 39, 381-393.

[33] Tsai, Y. (2012) The Effects of Intercultural Learning on English Learning Motivation among Students Studying Abroad. New Horizons in Education, 60, 23-34. 
[34] Pavlenko, A. and Lantolf, J. (2001) Second Language Learning as Participation and the Reconstruction of Selves. In: Lantolf, Ed., Sociocultural Theory and Second Language Learning, Oxford University Press, 155-177.

[35] Stephan, G.W. (1987) Contact Hypothesis in Intergroup Relations. Review of Personality and Social Psychology, 9, 13-40.

[36] Pettigrew, T.E. and Tropp, L.R. (2006) A Meta-Analytic Test of Intergroup Contact Theory. Journal of Personality and Social Psychology, 90, 751-783. https://doi.org/10.1037/0022-3514.90.5.751

[37] Clement, R. (1980) Ethnicity, Contact, and Communicative Competence in a Second Language. In: Giles, H.M., Robinson, W.P. and Smith, P.M., Eds., Language: Social Psychological Perspectives, Pergamon, Oxford, 147-154.

[38] Dornyei, Z (2001) Teaching and Researching Motivation. Longman, London.

[39] Roberts, A., Chou, P. and Ching, G. (2010) Contemporary Trends in East Asian Higher Education: Dispositions of International Students in a Taiwan University. Higher Education, 59, 149-166. https://doi.org/10.1007/s10734-009-9239-4

[40] Song, J. (2016) Identity: Conflicts, Vulnerability, and Transformation. TESOL Quarterly, 50, 631-654. https://doi.org/10.1002/tesq.312

[41] Su, L.J. and Kuo, H.W. (1993) Assessment of Practice Stress among Nursing Students in a Junior College-An Early State of Nursing Practice. Nursing Research, 1, 166-175, 1993.

[42] Sheu, S., Lin, H.-S. and Hwang, S.-L. (2001) The Relationships among Stress, Physio-Psycho-Social Status, Coping Behaviors and Personality Traits of Nursing Students during First Time Clinical Practice. Nursing Research, 9, 233-246.

[43] Yang, C.-L. (2011) Internationalized Medical Care Service Increase Need of Health Care Providers to Improve English Communication Skills. The Journal of Nursing, 58, 99-104.

[44] Lee, T.-C. (2016) Needs Analysis on English Language Use in Nursing: A Comparison between Certified Nurses and Student Nurses. A Thesis for Master of Arts, Department of English, Tamkang University, Taiwan

[45] Wang, C.C. and Greenwood, K.M. (2015) Chinese Nursing Students' Culture-Related Learning Styles and Behaviors: A Discussion Paper. International Journal of Nursing Sciences, 2, 253-258.

[46] Kitchens, J.L. (2003) Basic Statistics and Data Analysis. Thomas Learning Inc., Canada.

[47] Stake, R.E. (1988) Case Study Methods in Educational Research: Seeking Sweet Water. In: Jaeger, R.M., Ed., Complementary Methods for Research in Education, American Educational Research Association, Washington DC, 253-300.

[48] Liu, C. (2015) Relevant Researches on Tolerance of Ambiguity. Theory and Practice in Language Studies, 5, 1874-1882. https://doi.org/10.17507/tpls.0509.15

[49] Gay, L.R. (1992) Educational Research: Competencies for Analysis and Applications. 4th Edition, Macmillan Publishing Company, N.Y.

[50] Nunnally, J.C. (1978) Psychometric Theory. 2nd Edition, McGraw-Hill, New York.

[51] Panayides, P. (2013) Research Reports Coefficient Alpha. Europe's Journal of Psychology, 9, 687-696.

[52] Gardner, R.C. (1990) Attitudes, Motivation, and Personality as Predictors of Success in Foreign Language Learning. In: Parry, T.S. and Stanfield, C.W., Eds., Language Aptitude Reconsidered, Prentice Hall Regents, NJ, 179-221. 
[53] Hou, Y.-A. (2013) How Genders Differ in Taiwanese College Students' Multiple Intelligences and English Learning? International Conference Communication in the Computer and Information Science, HCI 2013, Las Vegas, 21-26 July 2013, Proceeding Book, 48-51.

[54] Shin, H. (2014) Social Class, Habitus, and Language Learning: The Case of Korean Early Study-Abroad Students. Journal of Language, Identity, and Education, 13, 99-103. https://doi.org/10.1080/15348458.2014.901821

[55] Hickey, D.T. (1997) Motivation and Contemporary Socio-Constructivist Instructional Perspectives. Educational Psychologist, 32, 175-193.

https://doi.org/10.1207/s15326985ep3203_3 